\title{
Article \\ Effectiveness of Columbianadin, a Bioactive Coumarin Derivative, in Perturbing Transient and Persistent $I_{\mathrm{Na}}$
}

\author{
Wei-Ting Chang ${ }^{1,2,3}$ and Sheng-Nan $\mathrm{Wu}^{4,5,6, *}$ \\ 1 Institute of Clinical Medicine, College of Medicine, National Cheng Kung University, Tainan 70101, Taiwan; \\ cmcvecho2@gmail.com \\ 2 Division of Cardiovascular Medicine, Chi-Mei Medical Center, Tainan 71004, Taiwan \\ 3 Department of Biotechnology, Southern Taiwan University of Science and Technology, Tainan 71004, Taiwan \\ 4 Institute of Basic Medical Sciences, National Cheng Kung University Medical College, Tainan 70101, Taiwan \\ 5 Department of Physiology, National Cheng Kung University Medical College, Tainan 70101, Taiwan \\ 6 Department of Medical Research, China Medical University, Taichung 40402, Taiwan \\ * Correspondence: cmcvecho@gmail.com; Tel.: +886-6-2353535-5334; Fax: +886-6-2362780
}

check for updates

Citation: Chang, W.-T.; Wu, S.-N. Effectiveness of Columbianadin, a Bioactive Coumarin Derivative, in Perturbing Transient and Persistent $I_{\text {Na. Int. J. Mol. Sci. 2021, 22, } 621 .}$ https://doi.org/10.3390/ijms22020621

Received: 6 December 2020

Accepted: 6 January 2021

Published: 9 January 2021

Publisher's Note: MDPI stays neutral with regard to jurisdictional clai$\mathrm{ms}$ in published maps and institutional affiliations.

Copyright: (C) 2021 by the authors. Licensee MDPI, Basel, Switzerland. This article is an open access article distributed under the terms and conditions of the Creative Commons Attribution (CC BY) license (https:// creativecommons.org/licenses/by/ $4.0 /)$.

\begin{abstract}
Columbianadin ( $\mathrm{CBN})$ is a bioactive coumarin-type compound with various biological activities. However, the action of $\mathrm{CBN}$ on the ionic mechanism remains largely uncertain, albeit it was reported to inhibit voltage-gated $\mathrm{Ca}^{2+}$ current or to modulate TRP-channel activity. In this study, whole-cell patch-clamp current recordings were undertaken to explore the modifications of CBN or other related compounds on ionic currents in excitable cells (e.g., pituitary $\mathrm{GH}_{3}$ cells and HL-1 atrial cardiomyocytes). $\mathrm{GH}_{3}$-cell exposure to $\mathrm{CBN}$ differentially decreased peak or late component of voltage-gated $\mathrm{Na}^{+}$current $\left(I_{\mathrm{Na}}\right)$ with effective $\mathrm{IC}_{50}$ of 14.7 or $2.8 \mu \mathrm{M}$, respectively. The inactivation time course of $I_{\mathrm{Na}}$ activated by short depolarization became fastened in the presence of CBN with estimated $K_{\mathrm{D}}$ value of $3.15 \mu \mathrm{M}$. The peak $I_{\mathrm{Na}}$ diminished by $10 \mu \mathrm{M}$ CBN was further suppressed by subsequent addition of either sesamin $(10 \mu \mathrm{M})$, ranolazine $(10 \mu \mathrm{M})$, or tetrodotoxin $(1 \mu \mathrm{M})$, but it was reversed by $10 \mu \mathrm{M}$ tefluthrin (Tef); however, further application of $10 \mu \mathrm{M}$ nimodipine failed to alter CBN-mediated inhibition of $I_{\mathrm{Na}}$. CBN $(10 \mu \mathrm{M})$ shifted the midpoint of inactivation curve of $I_{\mathrm{Na}}$ to the leftward direction. The CBN-mediated inhibition of peak $I_{\mathrm{Na}}$ exhibited tonic and use-dependent characteristics. Using triangular ramp pulse, the hysteresis of persistent $I_{\mathrm{Na}}$ enhanced by Tef was noticed, and the behavior was attenuated by subsequent addition of CBN. The delayed-rectifier or erg-mediated $\mathrm{K}^{+}$current was mildly inhibited by $10 \mu \mathrm{M} \mathrm{CBN}$, while it also slightly inhibited the amplitude of hyperpolarization-activated cation current. In HL-1 atrial cardiomyocytes, CBN inhibited peak $I_{\mathrm{Na}}$ and raised the inactivation rate of the current; moreover, further application of $10 \mu \mathrm{M}$ Tef attenuated CBN-mediated decrease in $I_{\mathrm{Na}}$. Collectively, this study provides an important yet unidentified finding revealing that $\mathrm{CBN}$ modifies $I_{\mathrm{Na}}$ in electrically excitable cells.
\end{abstract}

Keywords: columbianadin; voltage-gated $\mathrm{Na}^{+}$current; persistent $\mathrm{Na}^{+}$current; current kinetics; hysteresis; pituitary cell; heart cell

\section{Introduction}

Columbianadin $(\mathrm{CBN})$ is one of the main bioactive constituents isolated from the underground part of Angelica pubescens Maxim. f. biserrate Shan et Yuan (Angelicae Pubescentis Radix or "Duho [Dú huó]" in China). This compound is a coumarin-type compound (an angular dihydrofuranocoumarin), which is increasingly recognized to have various biological activities that include analgesic, anti-inflammatory, and antineoplastic effects [1-13]. This compound has been reported to induce changes in cellular proliferation or apoptosis [12,14]. It has been also previously demonstrated that carrageenan or lipopolysaccharide-induced inflammatory reaction was ameliorated by the application of CBN $[1,2,4,7]$.

There is growing evidence that CBN could be a regulator of membrane ionic currents $[9,10]$. CBN-mediated analgesia was previously disclosed to be closely associated 
with its adjustments on the expression of TRPV1 channels [8,9,15]. Earlier studies have also reported the ability of this compound to inhibit the strength of voltage-gated $\mathrm{Ca}^{2+}$ currents in dorsal root ganglion neurons derived from mice, suggesting a possible link to its analgesic action in neuropathic pain model $[10,16]$. Alternatively, it has been previously revealed to inhibit depolarization-induced $\mathrm{Ca}^{2+}$ uptake as well to suppress prolactin release in pituitary $\mathrm{GH}_{3}$ cells $[16,17]$.

There are nine isoforms (i.e., $\alpha$-subunits) of voltage-gated $\mathrm{Na}^{+}(\mathrm{Na} v)$ channel (i.e., $\mathrm{Na}_{\mathrm{V}}$ 1.1-1.9), which are presently known to exist in mammalian tissues, including endocrine system [18-20]. Earlier reports have demonstrated that several inhibitors known to preferentially block the late component of voltage-gated $\mathrm{Na}^{+}$current $\left(I_{\mathrm{Na}}\right)$, such as ranolazine (Ran), KMUP-1, or sesamin (SSM) [21,22]. $\mathrm{Na}_{\mathrm{V}}$ channels are also expressed in nonexcitable cells at a lower level [19]. However, to date, the need of how CBN or other related compounds is capable of interacting with $\mathrm{Na}_{\mathrm{V}}$ channels to modify the strength and/or gating of $I_{\mathrm{Na}}$ in different types of electrically excitable cells remains largely unmet.

In light of the above-described statements, the purpose of this study was to investigate whether the presence of $\mathrm{CBN}$ is capable of causing any perturbations on various types of ionic currents in pituitary tumor $\left(\mathrm{GH}_{3}\right)$ cells that include voltage-gated $I_{\mathrm{Na}}$, persistent $I_{\mathrm{Na}}\left(I_{\mathrm{Na}[\mathrm{P}]}\right)$, erg-mediated $\mathrm{K}^{+}$current $\left(I_{\mathrm{K}(\mathrm{erg})}\right)$, delayed-rectifier $\mathrm{K}^{+}$current $\left(I_{\mathrm{K}(\mathrm{DR})}\right)$, and hyperpolarization-activated cation current $\left(I_{\mathrm{h}}\right) . \mathrm{GH}_{3}$ cells have been used as a cell model to study the gating properties of $I_{\mathrm{Na}}[23,24]$, and $\mathrm{Na}_{\mathrm{V}}$ channels are known to be native to all secretory pituitary cells [20]. In particular, the results of the present experiments highlight a notion that $\mathrm{CBN}$ can yield a depressant action on $I_{\mathrm{Na}}$ in a concentration-, time-, and state-dependent manner in excitable cells (e.g., $\mathrm{GH}_{3}$ cells and HL-1 cardiomyocytes). The yet unidentified depressant action of this agent on $I_{\mathrm{Na}}$ reported herein is thought to be through its interaction with the $\mathrm{Na}_{\mathrm{V}}$ channel in the open or open/inactivated state.

\section{Results}

\subsection{Effect of Columbianadin ( $C B N$ ) on Voltage-Gated $\mathrm{Na}^{+}$Current $\left(\mathrm{I}_{\mathrm{Na}}\right)$ Recorded from $\mathrm{GH}_{3}$ Cells}

In the first stage of the whole-cell experiments, we examined the effects of $\mathrm{CBN}$ on the amplitude and gating of $I_{\mathrm{Na}}$ in response to abrupt membrane depolarization. $\mathrm{GH}_{3}$ cells were immersed in $\mathrm{Ca}^{2+}$-free, Tyrode's solution containing $10 \mathrm{mM}$ TEA, and we filled up the recording electrode with a $\mathrm{Cs}^{+}$-containing solution. As depicted in Figure 1A, within $1 \mathrm{~min}$ of exposing cells to CBN at a concentration of 3 or $10 \mu \mathrm{M}$, the amplitude in the peak and late (or end-pulse) components of $I_{\mathrm{Na}}$ activated by rapid membrane depolarization from -80 to $-10 \mathrm{mV}$ was progressively decreased. For example, as short step depolarization from -80 to $-10 \mathrm{mV}$ with a duration of $40 \mathrm{~ms}$ was applied (indicated in the inset of Figure 1A) to activate $I_{\mathrm{Na}}$, the addition of $10 \mu \mathrm{M} \mathrm{CBN}$ caused a conceivable decrease in the peak or late amplitude of $I_{\mathrm{Na}}$ to $913 \pm 63$ or $5.2 \pm 0.8 \mathrm{pA}(n=9, p<0.05)$, respectively, from the control values of $1521 \pm 212$ or $12.1 \pm 0.9 \mathrm{pA}(n=9)$. After removal of CBN, the peak or late amplitude of the current returned to $1456 \pm 186$ or $11.9 \pm 0.9 \mathrm{pA}(n=8, p<0.05)$.

Figure $1 \mathrm{~B}$ illustrates that the addition of $\mathrm{CBN}$ to the bath can concentration-dependently depress the amplitude of peak or late $I_{\mathrm{Na}}$ evoked in response to rapid membrane depolarization. According to the modified Hill equation detailed under Materials and Methods, the $\mathrm{IC}_{50}$ value required for $\mathrm{CBN}$-induced inhibition of peak or late $I_{\mathrm{Na}}$ observed in $\mathrm{GH}_{3}$ cells was calculated to be 14.7 or $2.8 \mu \mathrm{M}$, respectively, the value of which was evidently distinguishable between its effects on these two components of the current. The results, therefore, enable us to unravel that CBN has a depressant action on the peak and late $I_{\mathrm{Na}}$ natively expressed in $\mathrm{GH}_{3}$ cells and that this agent tends to be selective for late over peak $I_{\mathrm{Na}}$ in response to rapid depolarizing pulse. 

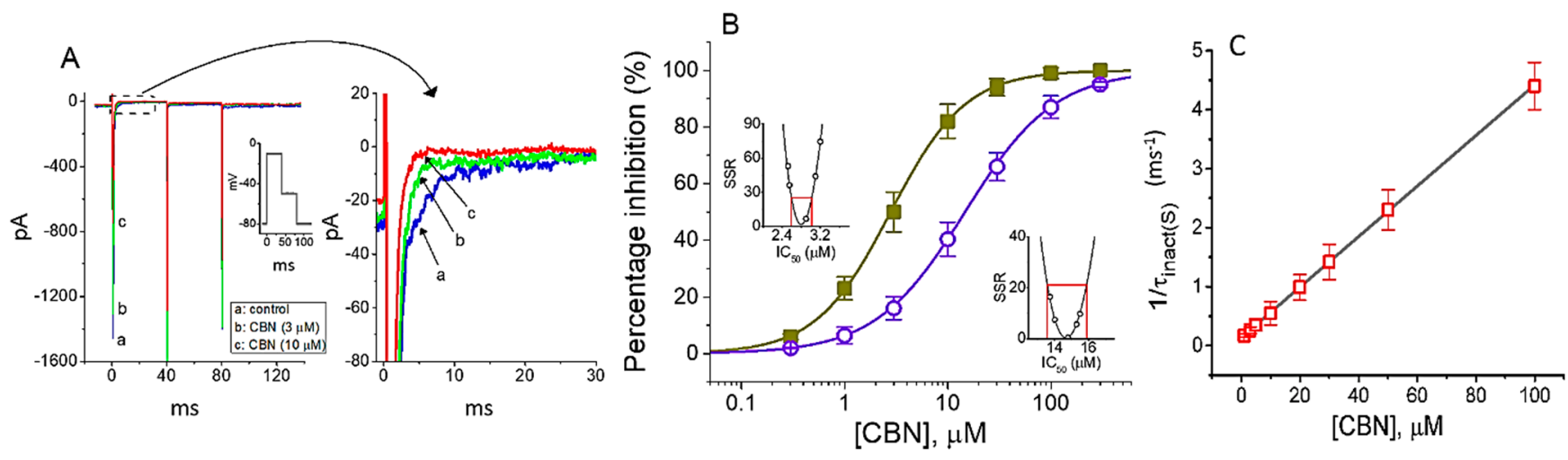

Figure 1. Effect of columbianadin $(\mathrm{CBN})$ on voltage-gated $\mathrm{Na}^{+}$current $\left(I_{\mathrm{Na}}\right)$ in pituitary tumor $\left(\mathrm{GH}_{3}\right)$ cells. The experiments were undertaken in cells bathed in $\mathrm{Ca}^{2+}$-free Tyrode's solution, and the recording electrode was filled up with $\mathrm{Cs}^{+}$-containing solution. (A) Typical current traces obtained in the control (a, i.e., CBN was not present) and in the presence of $3 \mu \mathrm{M} C B N$ (b) or $10 \mu \mathrm{M} \mathrm{CBN} \mathrm{(c).} \mathrm{The} \mathrm{insert} \mathrm{illustrates} \mathrm{the} \mathrm{voltage} \mathrm{protocol} \mathrm{applied.} \mathrm{The} \mathrm{right} \mathrm{panel} \mathrm{indicates} \mathrm{an} \mathrm{expanded} \mathrm{record}$ from the dashed box of (A). (B) Concentration-dependent relationship of CBN on peak $(\bigcirc)$ and late $(\boldsymbol{\square})$ components of $I_{\mathrm{Na}}$ elicited by rapid membrane depolarization (mean $\pm \mathrm{SEM} ; n=8$ for each point). Insets show confidence assessment of best-fit parameter values in the peak and late component of $I_{\mathrm{Na}}$ in response to short depolarizing voltage pulse from -80 to $-10 \mathrm{mV}$. Red line shown in each inset is placed at parameter value (i.e., $\mathrm{IC}_{50}$ ) at which the sum of squared residuals (SSR) in the peak or late component of $I_{\mathrm{Na}}$ amounts to $21 \%$ or $25 \%$ respectively, while the parameter range corresponds to the approximate $95 \%$ confidence interval. (C) The relation of $1 / \tau_{\text {inact(S) }}$ (i.e., the reciprocal of the slow component of current inactivation) versus the CBN concentration (mean \pm SEM; $n=8$ for each point). The value of $I_{\mathrm{Na}}$ inactivation was measured as the examined cells were $40 \mathrm{~ms}$ depolarized from -80 to -10 . Forward $\left(k_{+1}^{*}\right)$ or backward $\left(k_{-1}\right)$ rate constant, determined from the slope or the $y$-axis interacept of the interpolated line, was yielded to be $0.0428 \mathrm{~ms}^{-1} \mu \mathrm{M}^{-1}$ or $0.1348 \mathrm{~ms}^{-1}$, respectively.

\subsection{Kinetic Study of CBN Action on $I_{N a}$}

It was noticed that the inhibitory effects of $\mathrm{CBN}$ on $I_{\mathrm{Na}}$ in $\mathrm{GH}_{3}$ cells could not only emerge instantaneously (i.e., they vary in time) but they also occurred in a time- and concentration-dependent manner. In other words, the interaction of the CBN molecule with $\mathrm{Na}_{V}$ channel would develop with time after the channels are bound with the compound. In this regard, in attempts to provide quantitative estimation of CBN-induced block of $I_{\mathrm{Na}}$, we further analyzed the time constant of the slow component of $I_{\mathrm{Na}}$ inactivation $\left(\tau_{\text {inact }(\mathrm{S})}\right)$. The concentration-dependence of $\mathrm{CBN}$-induced block for $I_{\mathrm{Na}}$ in response to abrupt membrane depolarization is illustrated in Figure 1C. It is, therefore, evident from these data that the exposure to $\mathrm{CBN}$ resulted in a concentration-dependent increase in the rate constant (i.e., $\left.1 / \tau_{\text {inact(S) }}\right)$ of the slow component in $I_{\mathrm{Na}}$ inactivation. There was a linear relationship between the $1 / \tau_{\text {inact }(S)}$ value and the CBN concentration with a correlation coefficient of 0.96 (Figure 1C). The blocking $\left(k_{+}{ }^{*}\right)$ or unblocking $\left(k_{-1}\right)$ rate constant derived from such minimum binding (forward) and unbinding (backward) scheme was then calculated to be $0.0428 \mathrm{~ms}^{-1} \mu \mathrm{M}^{-1}$ or $0.1348 \mathrm{~ms}^{-1}$, respectively; consequently, the value of dissociation constant $\left(K_{\mathrm{D}}=k_{-1} / k_{+1}{ }^{*}\right)$ was yielded to be $3.15 \mu \mathrm{M}$. Moreover, this value achieved by this reaction scheme was found to be nearly similar to the $\mathrm{IC}_{50}$ value required for $\mathrm{CBN}$ mediated inhibition of the late $I_{\mathrm{Na}}$ measured at the end of depolarizing voltage pulse; however, it tends to be higher than that for block of peak $I_{\mathrm{Na}}$ (Figure 1B).

2.3. Comparison among Effects of CBN, CBN Plus Sesamin (SSM), CBN Plus Ranolazine (Ran), CBN Plus Tetrodotoxin (TTX), CBN Plus Nimodipine (Nim), and CBN Plus Tefluthrin (Tef) on Peak $\mathrm{I}_{\mathrm{Na}}$ Recorded from $\mathrm{GH}_{3}$ Cells

In another set of whole-cell experiments, we tested the possible effects of CBN, CBN plus different compounds, including SSM, Ran, TTX, Nim, and Tef, on the peak amplitude of $I_{\mathrm{Na}}$ activated in response to rapid membrane depolarization from -80 to $-10 \mathrm{mV}$. Either SSM, Ran, or TTX has been previously reported to inhibit $I_{\mathrm{Na}}$ effectively $[21,25]$, 
Nim is a specific inhibitor of L-type $\mathrm{Ca}^{2+}$ current [26], whereas Tef is a type-I pyrethroid insecticide known to activate $I_{\mathrm{Na}}$ [27]. As summarized in Figure 2, CBN $(10 \mu \mathrm{M})$ produced an inhibitory effect on the peak amplitude of $I_{\mathrm{Na}}$. In continued presence of CBN $(10 \mu \mathrm{M})$, the further addition of either SSM $(10 \mu \mathrm{M})$, Ran $(10 \mu \mathrm{M})$, or TTX $(1 \mu \mathrm{M})$ was effective at decreasing $I_{\mathrm{Na}}$ amplitude further. However, as cells were continually exposed to CBN $(10 \mu \mathrm{M})$, subsequent application of Tef $(10 \mu \mathrm{M})$, but not Nim $(10 \mu \mathrm{M})$, was able to attenuate CBN-induced block of peak $I_{\mathrm{Na}}$ seen in $\mathrm{GH}_{3}$ cells.

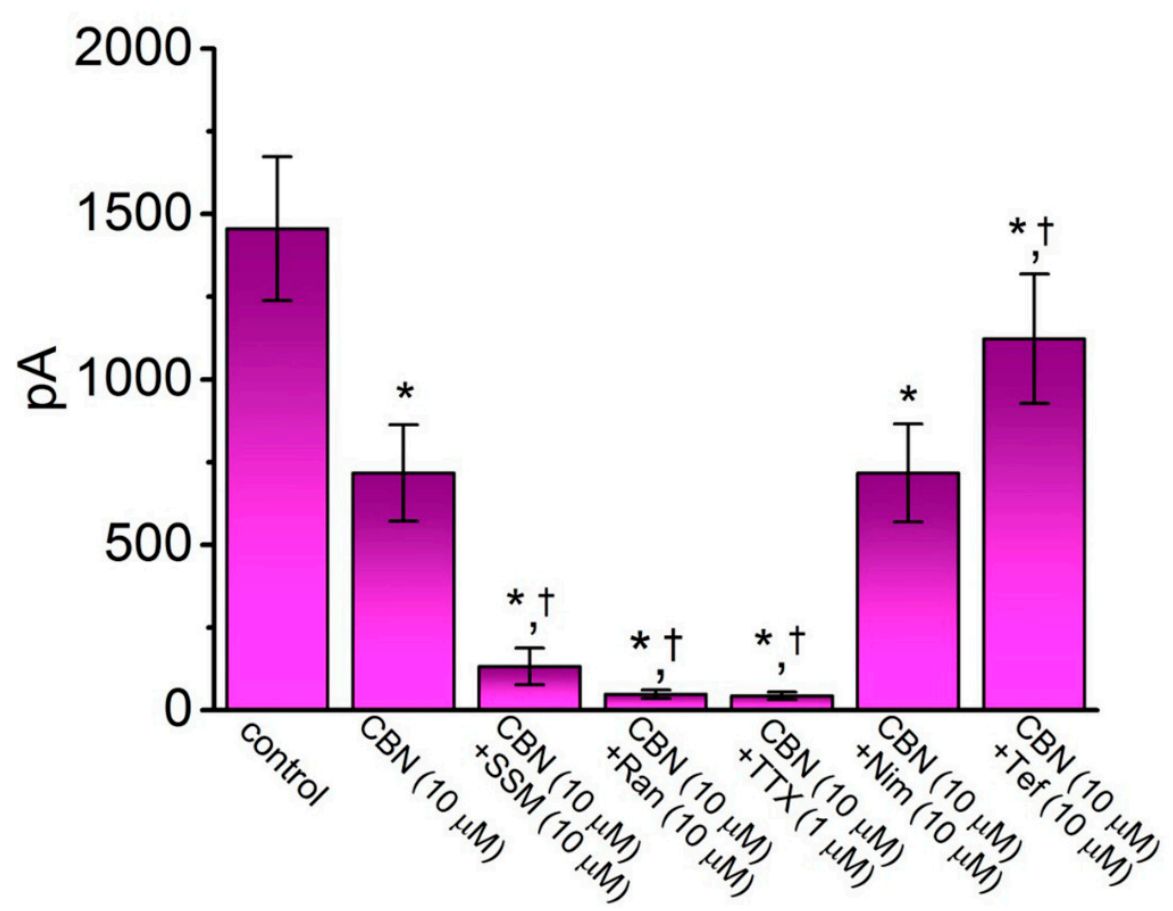

Figure 2. Comparison among effects of CBN, CBN plus sesamin (SSM), CBN plus ranolazine (Ran), CBN plus tetrodotoxin (TTX), CBN plus nimodipine (Nim), and CBN plus tefluthrin (Tef) on the amplitude of peak $I_{\mathrm{Na}}$ observed in GH $\mathrm{H}_{3}$ cells. Cells were bathed in $\mathrm{Ca}^{2+}$-free, Tyrode's solution, and the recording pipet was filled up with $\mathrm{Cs}^{+}$-containing solution. The $I_{\mathrm{Na}}$ was activated by 50-ms depolarizing voltage command from -80 to $-10 \mathrm{mV}$, and current amplitude at the beginning of the voltage pulse was measured. Each bar represents the mean $\pm \operatorname{SEM}(n=7-8)$. * indicates significantly different from control (i.e., none of the agents were present) $(p<0.05)$, and + indicates significantly different from CBN $(10 \mu \mathrm{M})$ alone group $(p<0.05)$.

\subsection{Lack of Effect of CBN on the Steady-State Activation Curve of $I_{N a}$}

To characterize the inhibitory effect of $\mathrm{CBN}$ on $I_{\mathrm{Na}}$, we next studied whether this compound might yield any changes in the steady-state action curve of $I_{\mathrm{Na}}$ recorded from $\mathrm{GH}_{3}$ cells. Figure $3 \mathrm{~A}$ depicts representative $I_{\mathrm{Na}}$ traces activated by a series of voltage pulses ranging between -80 and $0 \mathrm{mV}$ in $10-\mathrm{mV}$ increments from a holding potential of $-80 \mathrm{mV}$. The mean $I-V$ relationship of peak $I_{\mathrm{Na}}$ with or without the application of $10 \mu \mathrm{M} \mathrm{CBN}$ is illustrated in Figure 3B. It was noted that the value of threshold or maximal voltage for activation of $I_{\mathrm{Na}}$ did not differ between the absence and presence of $10 \mu \mathrm{M} \mathrm{CBN}$. Figure $3 \mathrm{C}$ depicts the relationship of $I_{\mathrm{Na}}$-conductance $\left(G_{\mathrm{Na}}\right)$ versus membrane potential collected in the control (i.e., $\mathrm{CBN}$ was not present) and during exposure to $10 \mu \mathrm{M} \mathrm{CBN}$. In the control, $V_{1 / 2}=-17.4 \pm 2.2 \mathrm{mV}$ and $q=3.1 \pm 0.8 e(n=7)$, while in the presence of $10 \mu \mathrm{M} \mathrm{CBN}$, $V_{1 / 2}=-17.8 \pm 2.3 \mathrm{mV}$ and $q=3.2 \pm 0.9 e(n=7)$. Certainly, the experimental results reflect that the value of neither $V_{1 / 2}$ nor the apparent gating charge $(q)$ for the steady-state activation curve of $I_{\mathrm{Na}}$ is perturbed in the presence of $10 \mu \mathrm{M} \mathrm{CBN}$. 

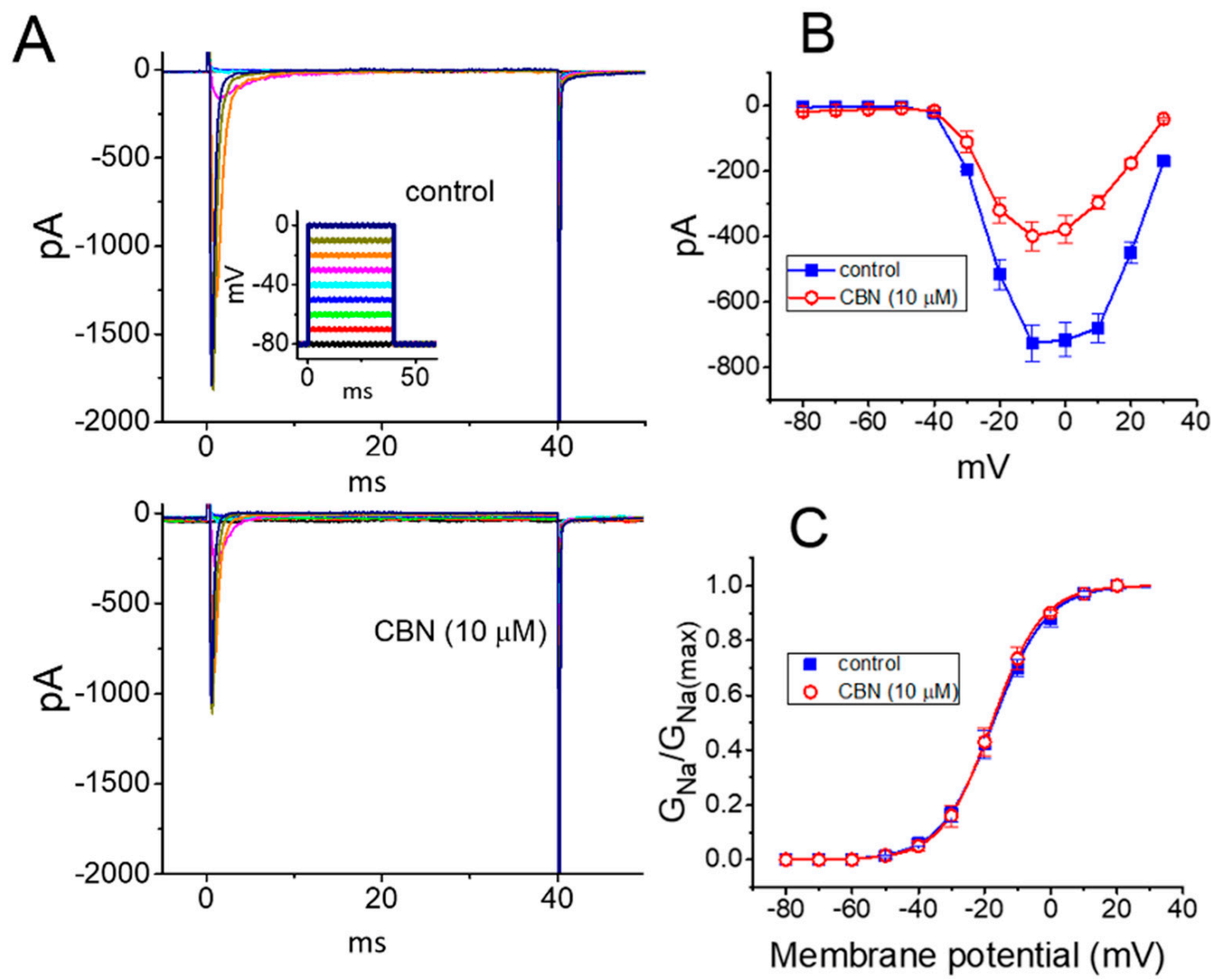

Figure 3. Effect of CBN on the current versus voltage $(I-V)$ and conductance versus voltage relationship of $I_{\mathrm{Na}}$ identified in $\mathrm{GH}_{3}$ cells. (A) Representative current traces activated by a series of voltage commands ranging from -80 to $0 \mathrm{mV}$ in $10-\mathrm{mV}$ increments. Current traces in the upper part are control, while those in the lower part were obtained in the presence of $10 \mu \mathrm{M}$ CBN. Inset in the upper part shows the voltage-clamp profile applied. (B) Mean $I-V$ relationship of peak $I_{\mathrm{Na}}$ obtained in the absence $(\boldsymbol{\square})$ and presence $(\bigcirc)$ of $10 \mu \mathrm{M} \mathrm{CBN}$ (mean $\pm \mathrm{SEM} ; n=7$ for each point). Current amplitude was measured at the beginning of each voltage command. (C) Mean conductance versus voltage relationship of peak $I_{\mathrm{Na}}$ taken in the control $(\boldsymbol{\square})$ and during the exposure $(\bigcirc)$ to $10 \mu \mathrm{M} \mathrm{CBN}$ (mean \pm SEM; $n=7$ for each point). Smooth line indicates the goodness-of-fit to the modified Boltzmann equation. Of notice, no obvious difference in conductance versus potential relationship with or without CBN addition was demonstrated.

\subsection{Steady-State Inactivation Curve of Peak $I_{N a}$ Obtained in the Absence or Presence of CBN}

Next, we assessed the steady-state inactivation curve of $I_{\mathrm{Na}}$ taken with or without the CBN addition. Two-step voltage-clamp protocol was used in this set of whole-cell experiments. The data with respect to the relationship of conditioning potential versus normalized amplitude of peak $I_{\mathrm{Na}}$ were constructed and a measure of goodness-of-fit for a modified Boltzmann equation fitted to the data set was thereafter performed. As depicted in Figure 4, the steady-state inactivation curve of $I_{\mathrm{Na}}$ could be modified in the presence of CBN $(10 \mu \mathrm{M})$. In the control, the resultant value for $V_{1 / 2}$ or $q$ was estimated to be $-53.7 \pm 2.5 \mathrm{mV}$ and $2.6 \pm 0.9 e(n=8)$, respectively; however, during $\mathrm{GH}_{3}$-cell exposure to $10 \mu \mathrm{M} \mathrm{CBN}$, that of $V_{1 / 2}$ or $q$ was $-62.6 \pm 2.6 \mathrm{mV}$ or $2.5 \pm 0.9 e(n=8)$, respectively. The data therefore enable us to reflect that the midpoint for the steady-state inactivation curve of peak $I_{\mathrm{Na}}$ was shifted along the voltage axis in a leftward direction by about $9 \mathrm{mV}$; however, there was void of clear adjustments in the apparent gating charge of the curve. 

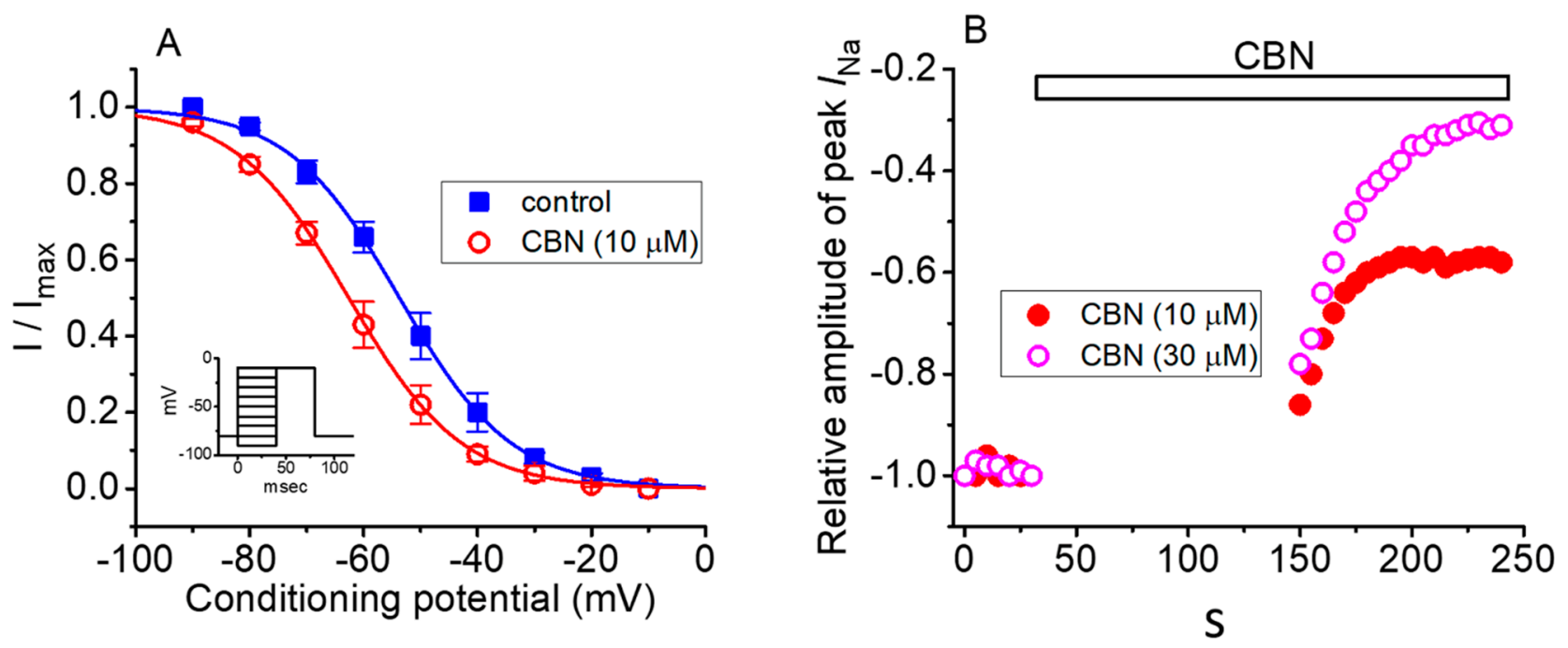

Figure 4. CBN-mediated change in the steady-state inactivation curve of peak $I_{\mathrm{Na}}(\mathbf{A})$ and its tonic-and use-dependent block of peak $I_{\mathrm{Na}}(\mathbf{B})$ in $\mathrm{GH}_{3}$ cells. In these experiments (A), cells were immersed in $\mathrm{Ca}^{2+}$-free Tyrode solution, while the examined cells were held at $-80 \mathrm{mV}$, and a series of the voltage pulses ranging between -90 and $-10 \mathrm{mV}$ (as indicated in inset) were given. $\mathbf{0}$ : control (i.e., CBN was not present) and $\bigcirc$ : in the presence of $10 \mu \mathrm{M} \mathrm{CBN}$. Each point represents the mean \pm SEM $(n=8)$. The sigmoid line shows the goodness-of-fit to the modified Boltzmann equation. Note that the inactivation curve of $I_{\mathrm{Na}}$ was shifted to a negative direction in the presence of $10 \mu \mathrm{M} \mathrm{CBN}$; however, there was lack of change in the apparent gating charge of the current. (B) Tonic- and use-dependent block of peak $I_{\mathrm{Na}}$ by CBN. The cell was held at $-80 \mathrm{mV}$ and the depolarizing pulse from -80 to $-10 \mathrm{mV}$ ( $40 \mathrm{~ms}$ in duration) was applied at $0.2 \mathrm{~Hz}$. The application of CBN $(10$ or $30 \mu \mathrm{M})$ is illustrated by a horizontal bar. Changes in the relative amplitude of peak $I_{\mathrm{Na}}$ during exposure to 10 or $30 \mu \mathrm{M} \mathrm{CBN}$ are illustrated. The peak $I_{\mathrm{Na}}$ in the control was taken as -1.0 . Immediately after the voltage pulses were stopped, various concentrations $(10$ or $30 \mu \mathrm{M})$ of CBN were added to the bath. The repetitive depolarizing pulses to $-10 \mathrm{mV}$ at $0.2 \mathrm{~Hz}$ were applied again $2 \mathrm{~min}$ after the cessation of command pulses, but still in the continued presence of CBN $(10 \mu \mathrm{M}[\bullet]$ or $30 \mu \mathrm{M}[\bigcirc])$. Of notice, in the presence of CBN, the peak $I_{\mathrm{Na}}$ activated by the first depolarizing step following a long pause (around $2 \mathrm{~min}$ ) had been already suppressed (i.e., tonic inhibition), and, during the repetitive stimuli, the amplitude of peak $I_{\mathrm{Na}}$ was further reduced exponentially (i.e., use-dependent inhibition).

\subsection{Use-Dependence of CBN-induced Inhibition of Peak $I_{N a}$}

This set of experiments was undertaken to evaluate the use-dependence property of CBN-mediated inhibition of peak $I_{\mathrm{Na}}$. As shown in Figure $4 \mathrm{~B}$, the depolarizing pulses from -80 to $-10 \mathrm{mV}$ ( $40 \mathrm{~ms}$ in duration) were applied at $0.2 \mathrm{~Hz}$. Under control condition (i.e., $\mathrm{CBN}$ was not present), no decline in the peak $I_{\mathrm{Na}}$ amplitude elicited at this simulation protocol was observed for more than $5 \mathrm{~min}$. When peak $I_{\mathrm{Na}}$ remained constant in $\mathrm{Ca}^{2+}$-free, Tyrode's solution, the depolarizing pulses were stopped, and CBN $(10$ or $30 \mu \mathrm{M})$ was then applied to the bath. After $2 \mathrm{~min}$ of cessation, the depolarizing pulses from -80 to $-10 \mathrm{mV}$ at $0.2 \mathrm{~Hz}$ were given to the cells again. The relative amplitude of peak $I_{\mathrm{Na}}$ with respect to that before the addition of CBN was constructed. It is illustrated in Figure 4B. Of notice, CBN-mediated inhibition of peak $I_{\mathrm{Na}}$ consists of both tonic and use-dependent components. For example, in the presence of $10 \mu \mathrm{M} \mathrm{CBN}$, after a 2-min pause, the peak $I_{\mathrm{Na}}$ evoked by the first voltage step was suppressed by $14 \% \pm 4 \%(n=7)$ (i.e., tonic inhibition). Moreover, following the repetitive stimuli, peak $I_{\mathrm{Na}}$ amplitude was further reduced to a constant level in an exponential fashion (i.e., use-dependent inhibition). The percentage inhibition of peak $I_{\mathrm{Na}}$ following the repetitive stimuli was increased to $39 \% \pm 5 \%(n=7)$. As the CBN concentration was increased to $30 \mathrm{mM}$, the peak $I_{\mathrm{Na}}$ amplitude at the first depolarizing pulse and during subsequent repetitive stimuli were significantly suppressed by $18 \% \pm 4 \%$ and $72 \% \pm 5 \%(n=7)$, respectively. The results indicated that CBN-mediated block of peak $I_{\mathrm{Na}}$ is composed of two components, namely, tonic and use-dependent components. 


\subsection{The Enhanced Amplitude by Tef of Persistent $\mathrm{Na}^{+}$Current $\left(I_{\mathrm{Na}(P)}\right)$ Attenuated by $\mathrm{CBN}$}

We next continued to explore whether the presence of CBN could modify the Tefenhanced $I_{\mathrm{Na}(\mathrm{P})}$ elicited in response to the slow triangular ramp pulse in $\mathrm{GH}_{3}$ cells. In these experiments, as the whole-cell current recordings were firmly established, we held the examined cell in voltage clamp at $-50 \mathrm{mV}$ and a $7.4 \mathrm{~s}$ upright isosceles-triangular ramp pulse ranging between -100 and $+50 \mathrm{mV}$ with a ramp speed of $\pm 0.04 \mathrm{mV} / \mathrm{ms}$ was applied. Of notice, in keeping with previous observations [27,28], when the cells were exposed to $10 \mu \mathrm{M}$ Tef alone, the amplitude of $I_{\mathrm{Na}(\mathrm{P})}$ activated at both upsloping (forward) and downsloping (backward) ends of such triangular ramp voltage was remarkably raised (Figure 5). For example, as cells were exposed to $10 \mu \mathrm{M}$ Tef, the peak $I_{\mathrm{Na}(\mathrm{P})}$ amplitude measured at the level of $0 \mathrm{mV}$ under the rising phase of triangular ramp pulse was considerably raised to $108 \pm 23 \mathrm{pA}(n=8, p<0.01)$ from a control value (measured at the same level of membrane potential) of $17 \pm 6 \mathrm{pA}(n=8)$. Meanwhile, in the presence of $10 \mu \mathrm{M}$ Tef, the peak $I_{\mathrm{Na}(\mathrm{P})}$ amplitude measured at $-60 \mathrm{mV}$ during the declining phase of triangular ramp was concurrently raised from $10 \pm 5$ to $131 \pm 26(n=8, p<0.01)$. Moreover, as shown in Figure 5, when cells were continually exposed to $10 \mu \mathrm{M}$ Tef, the subsequent addition of $10 \mu \mathrm{M}$ CBN further caused a significant reduction in the peak $I_{\mathrm{Na}}$ amplitude measured either at $0 \mathrm{mV}$ during the upsloping end of the triangular ramp pulse or at $-60 \mathrm{mV}$ during the downsloping end to $62 \pm 13$ or $62 \pm 14 \mathrm{pA}(n=8, p<0.05)$, respectively. These observations, therefore, prompted to reflect that the voltage-dependent hysteresis of $I_{\mathrm{Na}(\mathrm{P})}$ markedly occurred in the presence of Tef and that the subsequent application of CBN was capable of attenuating Tef-induced increase in the amplitude of $I_{\mathrm{Na}(\mathrm{P})}$ activated by either forward or backward end of long-lasting triangular ramp pulse observed in $\mathrm{GH}_{3}$ cells.
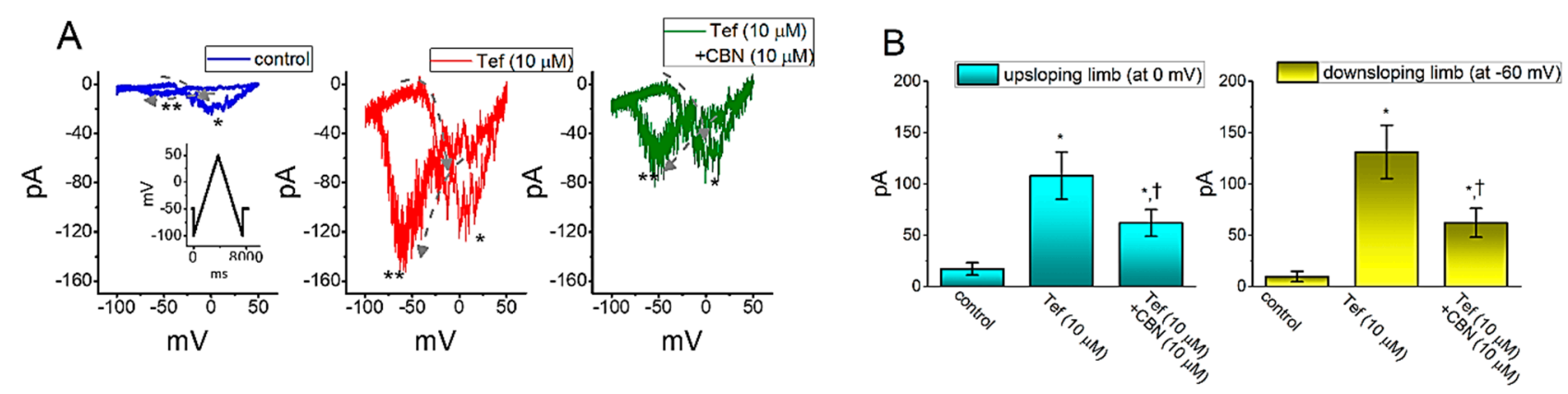

Figure 5. Inhibitory effect of CBN on tefluthrin (Tef) mediated increase in persistent $I_{\mathrm{Na}}$ current $\left(I_{\mathrm{Na}(\mathrm{P})}\right)$ in GH $\mathrm{G}_{3}$ cells. In these whole-cell current recordings, the cell was voltage-clamped at $-50 \mathrm{mV}$ and the isosceles-triangular ramp voltage with a duration of $7.4 \mathrm{~s}$ (i.e., ramp speed $= \pm 0.04 \mathrm{mV} / \mathrm{ms}$ ) was applied to activate $I_{\mathrm{Na}(\mathrm{P})}$ in response to the upsloping (from -100 to $+50 \mathrm{mV}$ ) and downsloping (from +50 to $-100 \mathrm{mV}$ ) ramp voltage-clamp command. (A) Representative current trace obtained in the control (left) and during the exposure to $10 \mu \mathrm{M}$ tefluthrin (Tef) (middle) or to $10 \mu \mathrm{M}$ Tef plus $10 \mu \mathrm{M}$ CBN. Inset in the left panel is the voltage-clamp protocol applied for all panels in (A), and dashed arrows in each panel show the direction of $I_{\mathrm{Na}(\mathrm{P})}$ in which time passes during the elicitation by the voltage-clamp command of upright isosceles-triangular ramp with a duration of $7.4 \mathrm{~s} .{ }^{*}$ and ${ }^{* *}$ indicate the amplitude of $I_{\mathrm{Na}(\mathrm{P})}$ activated by the upsloping (or forward) limb and downsloping (or backward) limb of the long-lasting triangular ramp pulse, respectively. (B) Summary bar graph showing the effects of tefluthrin (Tef, $10 \mu \mathrm{M})$ and Tef $(10 \mu \mathrm{M})$ plus CBN $(10 \mu \mathrm{M})$ on $I_{\mathrm{Na}(\mathrm{P})}$ amplitude activated by the upsloping and downsloping limb of $7.4 \mathrm{~s}$ triangular ramp pulse. Current amplitude shown in the left side was taken at the level of $0 \mathrm{mV}$ in the situations where the upsloping limb of triangular pulse was applied to evoke $I_{\mathrm{Na}(\mathrm{P})}$, while that in the right side was at the level of $-60 \mathrm{mV}$ during the downsloping end of the pulse. ${ }^{*}$ indicates significantly different from control $(p<0.01)$, and t indicates significantly different Tef $(10 \mu \mathrm{M})$ alone group $(p<0.05)$.

\subsection{Effect of $\mathrm{CBN}$ on erg-Mediated $\mathrm{K}^{+}$Current $\left(I_{K(\text { erg }}\right)$ in $\mathrm{GH}_{3}$ Cells}

We also extended to evaluate whether $\mathrm{CBN}$ could modify voltage-gated $\mathrm{K}^{+}$current (e.g., $I_{\mathrm{K}(\mathrm{erg})}$ ) enriched in $\mathrm{GH}_{3}$ cells. In order to amplify the magnitude of $I_{\mathrm{K}(\mathrm{erg})}$, we bathed cells in high- $\mathrm{K}^{+}, \mathrm{Ca}^{2+}$-free solution, and the recording electrode was backfilled with $\mathrm{K}^{+}$containing solution. The composition of these solutions used is detailed under Materials 
and Methods. In this set of whole-cell experiments, in order to evoke $I_{K(\mathrm{erg})}$, the examined cell was voltage-clamped at $-10 \mathrm{mV}$ and a series of $1 \mathrm{~s}$ hyperpolarizing pulses ranging between -100 and $-20 \mathrm{mV}$ was thereafter applied. As illustrated in Figure 6, the application of $10 \mu \mathrm{M} \mathrm{CBN}$ was noticed to decrease the amplitude of deactivating $I_{\mathrm{K}(\mathrm{erg})}$ observed throughout the entire voltage-clamp range examined. For example, as cells were exposed to $10 \mu \mathrm{M} \mathrm{CBN}$, the peak or late amplitude of $I_{\mathrm{K}(\mathrm{erg})}$ taken at the level of $-100 \mathrm{mV}$ was decreased to $346 \pm 55$ or $34 \pm 26 \mathrm{pA}(n=8, p<0.05)$ from a control value of $694 \pm 87$ or $81 \pm 32 \mathrm{pA}$, respectively. After washout of the agent, current amplitude at the beginning or end of hyperpolarizing pulse from -10 to $-100 \mathrm{mV}$ returned to $654 \pm 85$ or $78 \pm 29 \mathrm{pA}$, respectively $(n=7, p<0.05)$. These data indicate that $\mathrm{CBN}$ at a concentration of $10 \mu \mathrm{M}$ can depress the amplitude of hyperpolarization-elicited $I_{\mathrm{K}(\mathrm{erg})}$ by around $50 \%$ in $\mathrm{GH}_{3}$ cells.
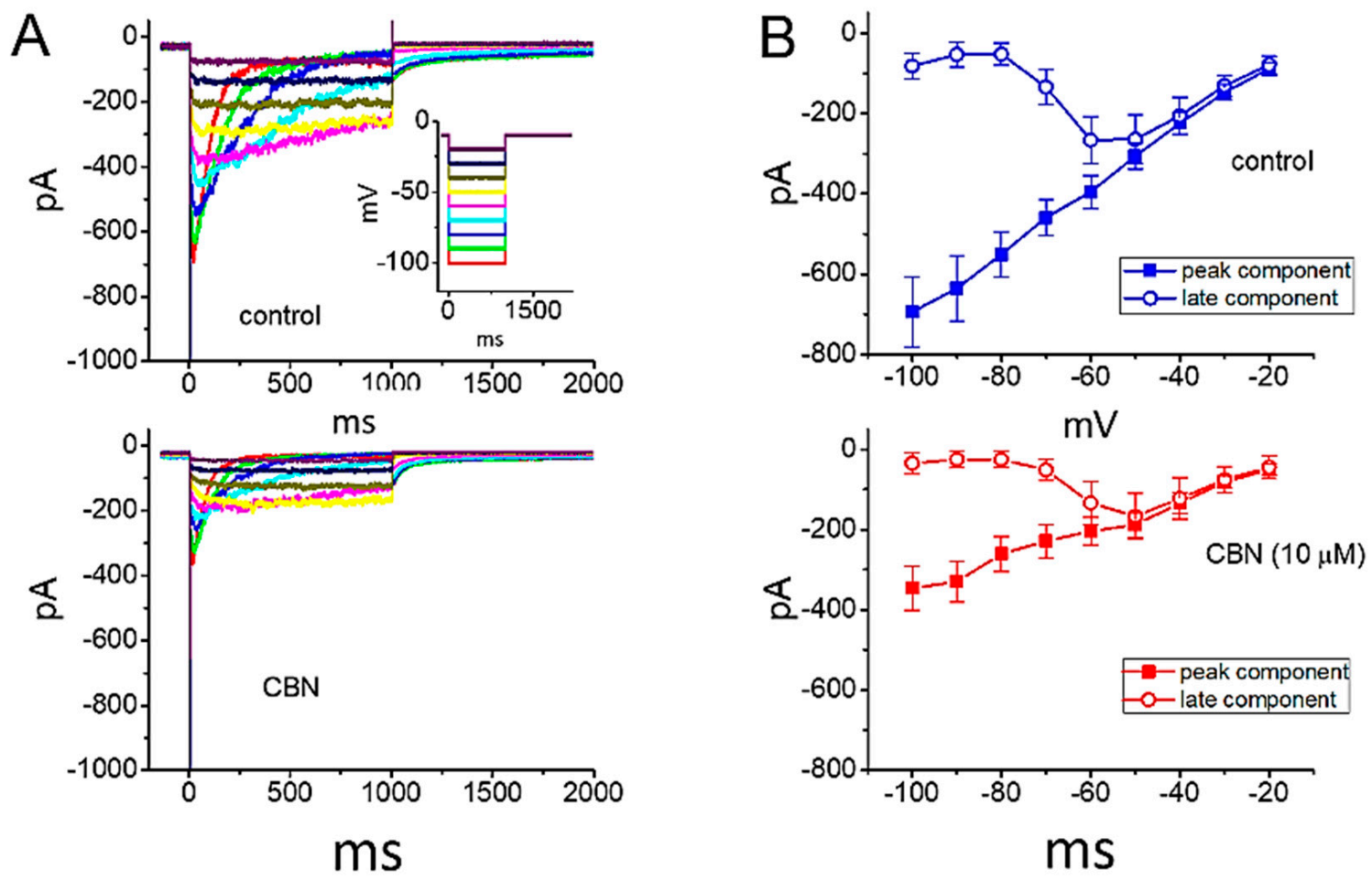

Figure 6. Inhibitory effect of $\mathrm{CBN}$ on erg-mediated $\mathrm{K}^{+}$current $\left(I_{\mathrm{K}(\mathrm{erg})}\right)$ identified in $\mathrm{GH}_{3}$ cells. In these experiments, we immersed cells in high- $\mathrm{K}^{+}, \mathrm{Ca}^{2+}$-free solution, and we filled up the pipet using $\mathrm{K}^{+}$-containing solution. (A) Representative current traces obtained in the absence (upper) and presence (lower) of $10 \mu \mathrm{M}$ CBN. Inset in the upper panel shows the voltage-clamp protocol applied. (B) Mean $I-V$ relationship of peak $I_{\mathrm{K}(\mathrm{erg})}$ (filled squares) and late $I_{\mathrm{K}(\mathrm{erg})}$ (open circles) recorded from these cells (mean $\pm \mathrm{SEM} ; n=8$ for each point). The upper or lower panel depicts the $I-V$ relationship of the current in the absence (blue color) or presence (red color) of $10 \mu \mathrm{M} \mathrm{CBN}$, respectively. Current amplitude (peak or late component) was measured at the start or the end of 1-s hyperpolarizing pulse from $-10 \mathrm{mV}$ to various voltage steps ranging between -100 and $-20 \mathrm{mV}$ in $10-\mathrm{mV}$ step.

\subsection{Effect of $C B N$ on Delayed-Rectifier $\mathrm{K}^{+}$Current $\left(I_{K(D R)}\right)$ in $\mathrm{GH}_{3}$ Cells}

In the next series of experiments, we continued to test whether the presence of $\mathrm{CBN}$ might modify another type of $\mathrm{K}^{+}$current (i.e., $I_{\mathrm{K}(\mathrm{DR})}$ ) enriched in these cells. Cells were bathed in $\mathrm{Ca}^{2+}$-free, Tyrode's solution, which contained $1 \mu \mathrm{M}$ TTX, while the recording pipette used was filled with $\mathrm{K}^{+}$-containing solution. As illustrated in Figure 7A,B, CBN at a concentration of 3 or $10 \mu \mathrm{M}$ could mildly suppress the amplitude of $I_{\mathrm{K}(\mathrm{DR})}$ activated by membrane depolarization; however, the inactivation time course of the current was little altered. For example, as cells were exposed to $10 \mu \mathrm{M}$ CBN, the $I_{\mathrm{K}(\mathrm{DR})}$ activated by depolarizing pulse from -50 to $+50 \mathrm{mV}$ was decreased by $34 \% \pm 2 \%$ to $202 \pm 21 \mathrm{pA}$ ( $n=8$, $p<0.05)$ from a control value of $306 \pm 24 \mathrm{pA}(n=8)$. After the compound was washed 
out, current amplitude returned to $294 \pm 23 \mathrm{pA}(n=7)$. Figure 7B depicts the mean $I-V$ relationship of $I_{\mathrm{K}(\mathrm{DR})}$ obtained in the absence or presence of $10 \mu \mathrm{M} \mathrm{CBN}$.

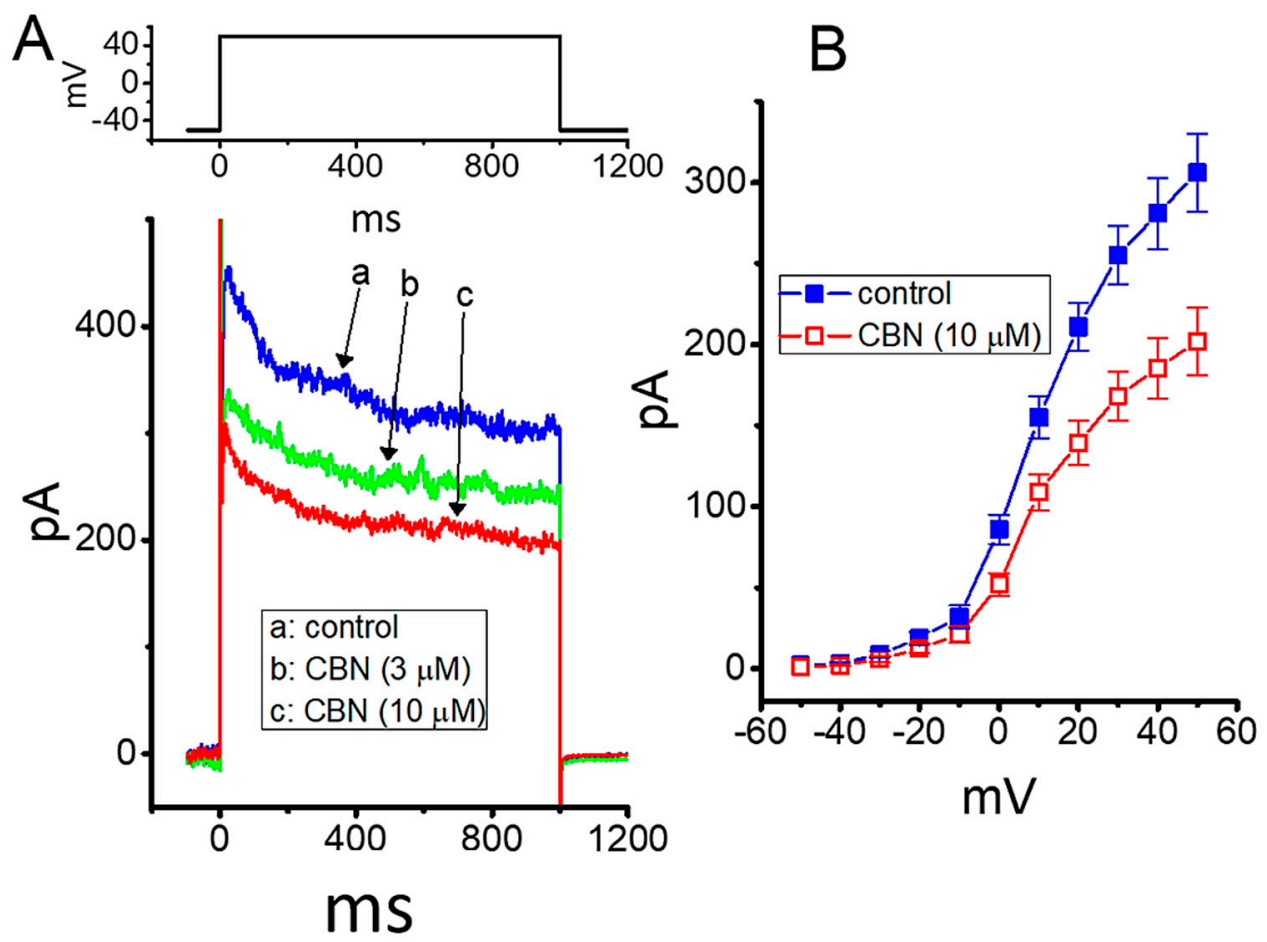

Figure 7. Effect of $\mathrm{CBN}$ on delayed-rectifier $\mathrm{K}^{+}$current $\left(I_{\mathrm{K}(\mathrm{DR})}\right)$ in $\mathrm{GH}_{3}$ cells. In this set of experiments, cells were bathed in $\mathrm{Ca}^{2+}$-free, Tyrode's solution containing $1 \mu \mathrm{M}$ TTX, and we filled the electrode with $\mathrm{K}^{+}$-containing solution. (A) Representative current traces obtained in the absence (a) and presence of $3 \mu \mathrm{M} \mathrm{CBN} \mathrm{(b)} \mathrm{or} 10 \mu \mathrm{M} \mathrm{CBN} \mathrm{(c).} \mathrm{(B)} \mathrm{Mean}$ $I-V$ relationship of $I_{\mathrm{K}(\mathrm{DR})}$ without $(\mathbf{\square})$ or with $(\bigcirc)$ the addition of $10 \mu \mathrm{M} \mathrm{CBN}$ (mean $\pm \mathrm{SEM} ; n=7$ for each point). Current amplitude was taken at the end of each depolarizing voltage command from a holding potential of $-50 \mathrm{mV}$ with a duration of $1 \mathrm{~s}$.

\subsection{Effect of $C B N$ on Hyperpolarization-Activated Cation Current $\left(I_{h}\right)$ in $\mathrm{GH}_{3}$ Cells}

We next investigated how cell exposure to $C B N$ could perturb the amplitude and gating of $I_{h}$ identified in $\mathrm{GH}_{3}$ cells [29]. In these experiments, we bathed cells in $\mathrm{Ca}^{2+}$-free, Tyrode's solution containing $1 \mu \mathrm{M}$ TTX and the recording electrode was filled up with $\mathrm{K}^{+}$-containing solution. As demonstrated in Figure 8, the application of $10 \mu \mathrm{M}$ CBN to the bath mildly lessened $I_{\mathrm{h}}$ amplitude activated by $2 \mathrm{~s}$ step hyperpolarization from -40 to $-120 \mathrm{mV}$, which was noticed to coincide with a lengthening in the activation time constant of $I_{\mathrm{h}}$. However, no change in the instantaneous amplitude of $I_{\mathrm{h}}$ as recently reported [30] was detected in the presence of CBN. For example, when cells were exposed to $10 \mu \mathrm{M}$ CBN, the $I_{\mathrm{h}}$ amplitude measured at the end of 2-s hyperpolarizing pulse was mildly but significantly reduced by $9 \% \pm 1 \%$ to $446 \pm 29 \mathrm{pA}(n=7, p<0.05)$ from a control value of $492 \pm 34 \mathrm{pA}$. Moreover, subsequent application of $10 \mu \mathrm{M}$ ivabradine (IVA) or $10 \mu \mathrm{M}$ dexmedetomidine (DEX), but still in the presence of CBN, was able to decrease $I_{\mathrm{h}}$ magnitude further, as demonstrated by a significant reduction in current amplitude to $62 \pm 9 \mathrm{pA}(n=7, p<0.05)$ or $66 \pm 12 \mathrm{pA}(n=7, p<0.05)$. IVA or DEX was previously reported to block $I_{\mathrm{h}}$ effectively $[15,31]$. It is evident, therefore, that cell exposure to CBN can result in a mild decrease in IVA-sensitive $I_{\mathrm{h}}$ amplitude activated in response to long-lasting membrane hyperpolarization. 

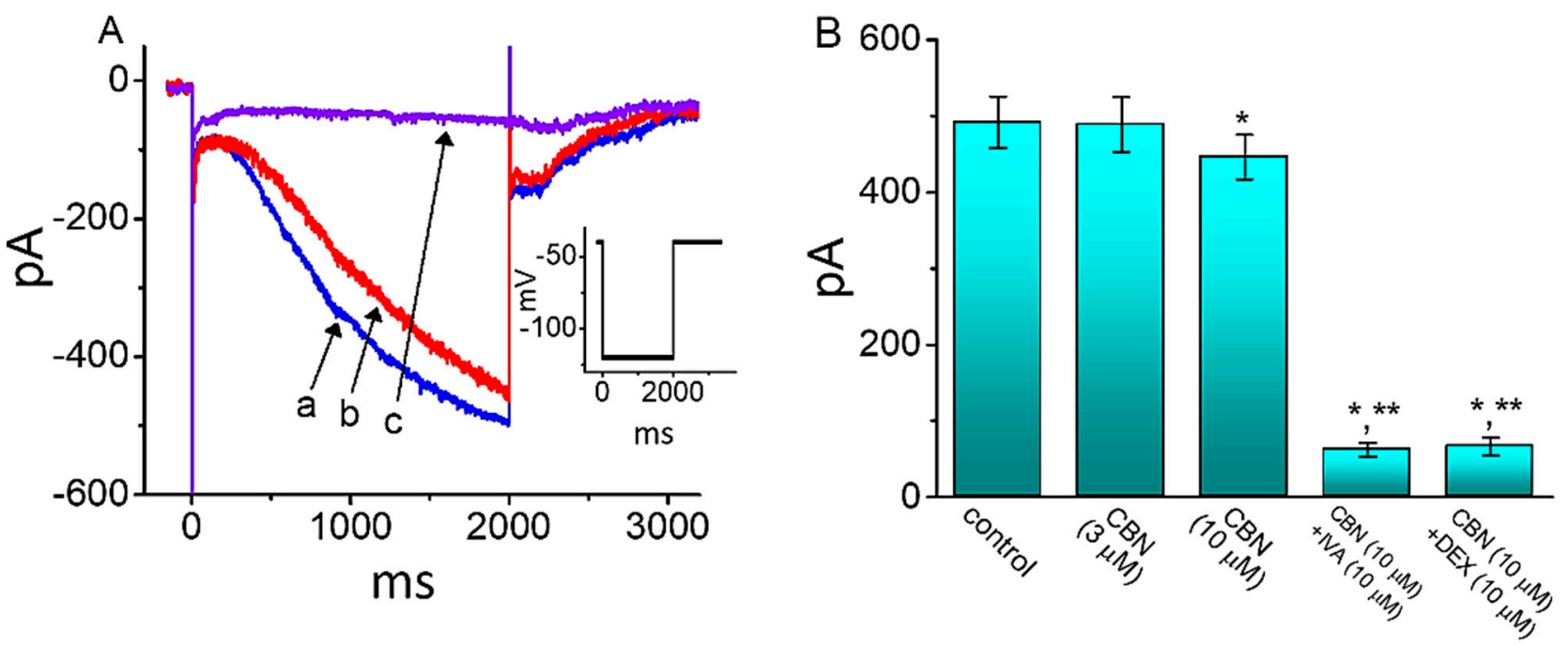

Figure 8. Effect of CBN on hyperpolarization-activated cation current $\left(I_{\mathrm{h}}\right)$ in $\mathrm{GH}_{3}$ cells. Cells were bathed in $\mathrm{Ca}^{2+}$-free, Tyrode's solution and the pipet were backfilled with $\mathrm{K}^{+}$-containing solution. (A) Representative current traces obtained in the absence (a) and presence of $10 \mu \mathrm{M} \mathrm{CBN} \mathrm{(b)} \mathrm{or} 10 \mu \mathrm{M} C B N$ plus $10 \mu \mathrm{M}$ ivabradine (IVA) (c). Inset depicts the voltage protocol used. (B) Summary bar graph demonstrating effect of $10 \mu \mathrm{M} \mathrm{CBN}$ and $10 \mu \mathrm{M}$ CBN plus $10 \mu \mathrm{M}$ ivabradine (IVA) on the amplitude of $I_{\mathrm{h}}$ (mean $\pm \mathrm{SEM} ; n=7$ for each bar). Current amplitude was taken at the end of $2 \mathrm{~s}$ hyperpolarizing pulse from -40 to $-120 \mathrm{mV} .{ }^{*}$ indicates significantly different from control $(p<0.05)$ and ${ }^{* *}$ indicates significantly different from $10 \mu \mathrm{M}$ CBN alone group $(p<0.05)$.

\subsection{Inhibitory Effect of CBN on $I_{N a}$ Identified from HL-1 Cardiomyocytes}

The CBN-perturbed changes in the properties of $I_{\mathrm{Na}}$ seen in $\mathrm{GH}_{3}$ cells may be different from those in heart cells. As such, in a final set of experiments, we attempted to explore whether the $I_{\mathrm{Na}}$ existing in another type of excitable cells (e.g., HL-1 atrial cardiomyocytes) can be influenced by the presence of CBN. For these current recordings, HL-1 cells were bathed in $\mathrm{Ca}^{2+}$-free, Tyrode's solution containing $10 \mathrm{mM}$ TEA and the recording electrode was filled with $\mathrm{Cs}^{+}$-containing solution. As illustrated in Figure 9, as the examined cell was depolarized from -80 to $-10 \mathrm{mV}$, the $I_{\mathrm{Na}}$ with rapid activation and inactivation was readily elicited [27]. As cells were exposed to 3 or $10 \mu \mathrm{M} \mathrm{CBN}$, the peak amplitude of $I_{\mathrm{Na}}$ was progressively decreased, which coincided with an increase in inactivation rate constant of the current activated in response to rapid membrane depolarization. For example, in the presence of $10 \mu \mathrm{M} \mathrm{CBN}$, the peak $I_{\mathrm{Na}}$ was decreased from $492 \pm 42$ to $204 \pm 24 \mathrm{pA}$ $(n=8, p<0.05)$. Concomitantly, the $\tau_{\text {inact(S) }}$ value of $I_{\mathrm{Na}}$ inactivation was also reduced from $6.2 \pm 0.9$ to $3.1 \mathrm{~ms}(n=8, p<0.05)$. After washout of the agent, current amplitude returned to $486 \pm 38 \mathrm{pA}(n=8, p<0.05)$. Moreover, as cells were continually exposed to $10 \mu \mathrm{M} \mathrm{CBN}$, the subsequent addition of $10 \mu \mathrm{M}$ Tef was able to reverse $\mathrm{CBN}$-mediated inhibition of peak $I_{\mathrm{Na}}$ effectively in HL-1 cells. Therefore, the emerging data showed that, similar to $I_{\mathrm{Na}}$ in $\mathrm{GH}_{3}$ cells described above, the $I_{\mathrm{Na}}$ in HL-1 cells was subjected to clear inhibition by CBN, although the results are to some extent distinguishable from those obtained from dorsal root ganglion neurons [10]. 


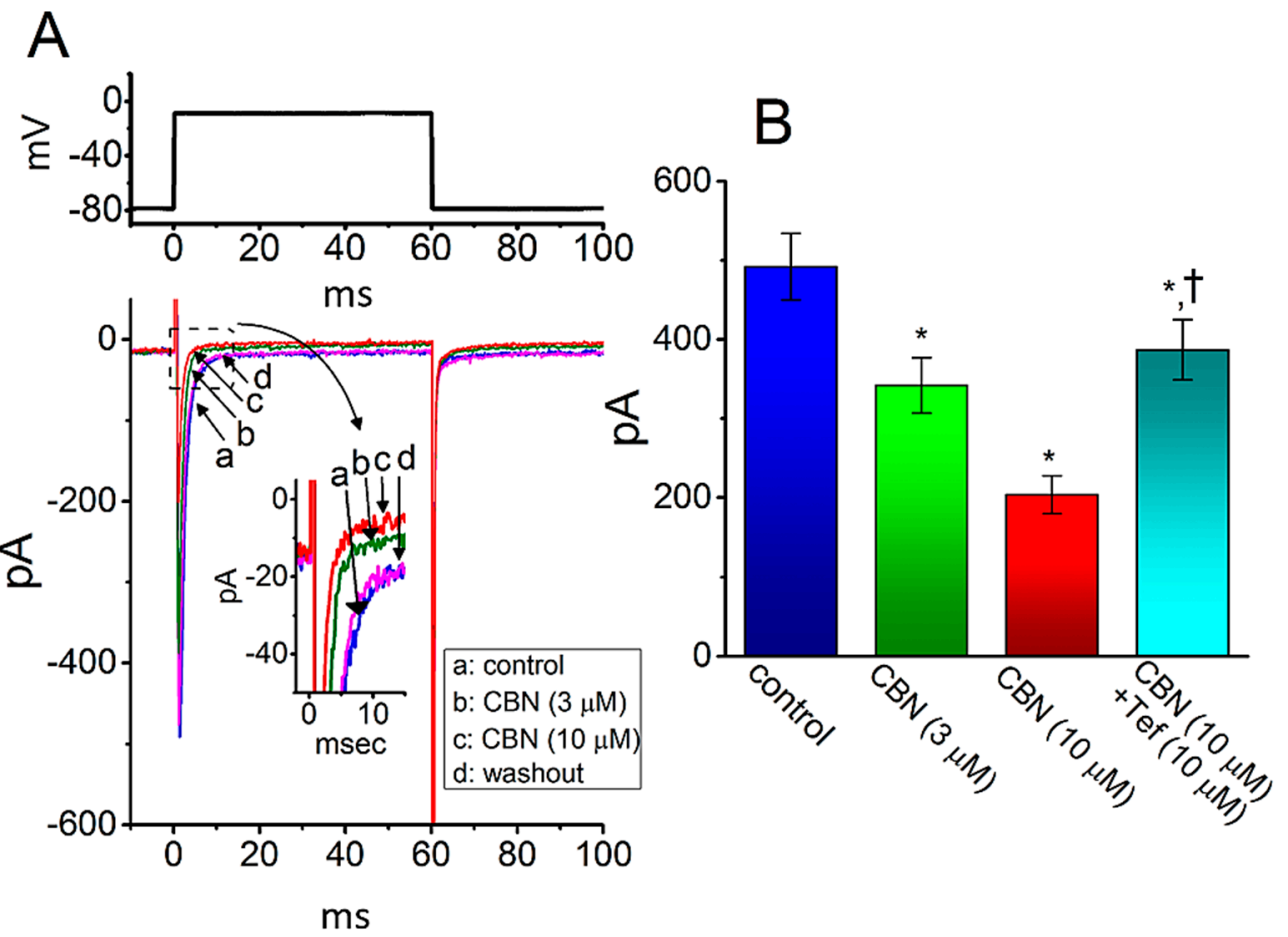

Figure 9. Effect of CBN on the amplitude of $I_{\mathrm{Na}}$ recorded from HL-1 atrial cardiomyocytes. The whole-cell current recordings were conducted in cells, which were bathed in $\mathrm{Ca}^{2+}$-free, Tyrode's solution, and we backfilled the electrode with $\mathrm{Cs}^{+}$-containing solution. (A) Representative current traces activated by 60-ms depolarizing pulse from -80 to $-10 \mathrm{mV}$ (indicated in the upper part). a: control (i.e., CBN was not present), b: $3 \mu \mathrm{M} \mathrm{CBN}, \mathrm{c}: 10 \mu \mathrm{M}$ CBN, and d: washout of the agent. Inset in (A) indicates the expanded record from dashed box. (B) Summary bar graph demonstrating effect of CBN and CBN plus tefluthrin (Tef) on the peak amplitude of $I_{\mathrm{Na}}$ in HL- 1 cells (mean $\pm \mathrm{SEM} ; n=8$ for each bar). Current amplitude was taken at the start of depolarizing pulse from -80 to $-10 \mathrm{mV}$. * indicates significantly different from control $(p<0.05)$ and + indicates significantly different from CBN $(10 \mu \mathrm{M})$ alone group $(p<0.05)$.

\section{Discussion}

The principal results of the present work are that (a) the presence of CBN could depress $I_{\mathrm{Na}}$ in a concentration-, time-, and state-dependent manner in $\mathrm{GH}_{3}$ cells, (b) this compound differentially inhibited the peak and late amplitudes of $I_{\mathrm{Na}}$ activated by rapid membrane depolarization with effective $\mathrm{IC}_{50}$ of 14.7 and $2.8 \mu \mathrm{M}$, respectively, (c) it shifted the midpoint of $I_{\mathrm{Na}}$ inactivation curve along the voltage axis to a negative potential, despite inability to alter the activation curve of the current, (d) it suppressed peak $I_{\mathrm{Na}}$ in a tonic and use-dependent manner, (e) subsequent addition of CBN was capable of depressing the Tef-induced increase in the $I_{\mathrm{Na}(\mathrm{P})}$ amplitude activated by the upright isosceles-triangular ramp at either upsloping or downsloping limb, and (f) it mildly inhibited the amplitude of $I_{\mathrm{K}(\mathrm{DR})}, I_{\mathrm{K}(\mathrm{erg})}$, or $I_{\mathrm{h}}$, and (g) in HL-1 cardiomyocytes, and CBN was effective at depressing $I_{\mathrm{Na}}$ as well as at decreasing the $\tau_{\text {inact(S) }}$ value of the current. The experimental results enable us to reflect that CBN-mediated change in the amplitude and gating kinetics of ionic currents presented herein tends to be upstream of its action either on cytosolic NOD1/Nf$\mathrm{KB}$ activation $[2,5,31]$ or on the activity of antioxidant enzymes [14], and that it could conceivably participate in the adjustments on different functional activities in electrically excitable cells (e.g., $\mathrm{GH}_{3}$ or HL-1 cells) occurring in vivo.

It is important to mention that the effect of $C B N$ on the time course of $I_{\mathrm{Na}}$ inactivation is continuously changing over time. Cell exposure to CBN tends to raise the rate of current inactivation during rapid membrane depolarization, enabling us to suggest that such molecule has the propensity to reach the blocking site only when the $\mathrm{Na}_{\mathrm{V}}$ channel resides in the open or inactivated state. As such, aside from its effective inhibition of peak $I_{\mathrm{Na}}$ amplitude, the CBN molecule may primarily interact on the activation and/or inactivation 
process, presumably resulting in the adjustments on both the magnitude and gating kinetics of the current, although the detailed underlying mechanism of its action on $I_{\mathrm{Na}}$ still remains to be resolved. Indeed, according to quantitative estimate from the heuristic binding scheme stated above, the $K_{\mathrm{D}}$ value required for $\mathrm{CBN}$-perturbed inactivation time course of $I_{\mathrm{Na}}$ (i.e., $\tau_{\text {inact(S) }}$ ) seen in $\mathrm{GH}_{3}$ cells was yielded to be $3.15 \mu \mathrm{M}$, a value which is actually close to the $\mathrm{IC}_{50}$ value needed for its inhibition of late $I_{\mathrm{Na}}$. Additionally, since the block of peak $I_{\mathrm{Na}}$ caused by CBN was noticed to consist of tonic and use-dependent components, it is likely that the intrinsic inactivation kinetics of the current could be altered in its presence.

In this study, the presence of CBN was unable to modify the steady-state activation curve (i.e., $G_{\mathrm{Na}}$ versus membrane potential relationship) of peak $I_{\mathrm{Na}}$ identified in $\mathrm{GH}_{3}$ cells. However, the steady-state inactivation curve of peak $I_{\mathrm{Na}}$ during its exposure $(10 \mu \mathrm{M})$ was noticed to shift toward a hyperpolarized potential by about $9 \mathrm{mV}$; however, there is void of changes in the gating charge of the curve. Consequently, the sensitivity of nonvoltageclamped excitable cells (e.g., neurons or endocrine cells) to this agent would be assumed to rely on different confounding variables, which include the pre-existing level of resting membrane potential, the pattern of action potential firing, the CBN concentration achieved, or that occurring in any combinations [20].

In the present study, the voltage-dependent hysteresis of $I_{\mathrm{Na}(\mathrm{P})}$ during exposure to Tef was observed by the long-lasting upright isosceles-triangular ramp voltage command with a ramp speed of $0.04 \mathrm{mV} / \mathrm{ms}$, although such hysteresis was barely observed in the control (i.e., Tef was not present). The peak $I_{\mathrm{Na}(\mathrm{P})}$ activated at the upsloping limb of such triangular ramp was noted to be placed at around $-0 \mathrm{mV}$, while that at the downsloping limb was markedly shifted to $-60 \mathrm{mV}$. Tef-induced $I_{\mathrm{Na}(\mathrm{P})}$ existing detected in $\mathrm{GH}_{3}$ cells was observed to undergo hysteresis in its voltage dependence. It is likely that such $I_{\mathrm{Na}(\mathrm{P})}$ during the exposure to Tef could intrinsically possess "memory" of previous events (or dynamic voltage dependence of $\left.I_{\mathrm{Na}(\mathrm{P})}\right)$ or that mode shift occurs with respect to the voltage sensitivity of gating charge movement, which relies on the previous state (or conformation) of the $\mathrm{Na}_{V}$-channel $[32,33]$. Such unique hysteretic behavior would play substantial role in influencing electrical behavior or sodium overload of excitable cells during exposure to such pyrethroid insecticides $[23,27,28]$. Moreover, the addition of CBN $(10 \mu \mathrm{M})$, but not that of chlorotoxin $(1 \mu \mathrm{M})$, still in the presence of Tef, was observed to be effective at attenuate Tef-induced $I_{\mathrm{Na}(\mathrm{P})}$ detected at both upsloping and downsloping limbs of the triangular ramp pulse.

The intestinal absorption and transportation of CBN has been previously reported $[27,34]$. This compound was noticed to be readily absorbed into blood stream and well distributed into various organs after intravenous or oral administration to rats [11,35-37]. Moreover, by use of liquid chromatography tandem mass spectrometry, the peak CBN level in rats following intravenous administration $(5 \mathrm{mg} / \mathrm{Kg})$ was previously measured to reach around $4.7 \mu \mathrm{g} / \mathrm{mL}$ (or $14 \mu \mathrm{M}$ ) [37,38]. This value is similar to effective $\mathrm{IC}_{50}$ required for its inhibition of peak $I_{\mathrm{Na}}$ presented herein; however, it is virtually higher than either that for block of late $I_{\mathrm{Na}}$ or the $K_{\mathrm{D}}$ value optimally estimated from the binding scheme. Therefore, it is likely that the $\mathrm{CBN}$ actions on ionic currents reported in $\mathrm{GH}_{3}$ or $\mathrm{HL}-1$ cells are of therapeutic and pharmacological relevance, if similar in-vivo findings occur.

A recent study reported ineffectiveness of CBN in modifying $I_{\mathrm{Na}}$ in small dorsal root ganglion neurons [10]. Conversely, finding from our results disclosed that CBN could be effective at inhibiting the magnitude of $I_{\mathrm{Na}}$ inherently in $\mathrm{GH}_{3}$ cells, favorably at the late (pulse-end) component of the current, which coincided with the increased inactivation rate. This discrepancy is currently unknown; however, it could be due to the view that different $\mathrm{Na}_{\mathrm{V}}$-channel isoforms or auxiliary $\alpha$-subunits exist in various types of electrically excitable cells. It was noticed that the $S C N 5 A$-encoded or $\mathrm{Na}_{\mathrm{V}} 1.5$ current is robustly expressed in heart cells, while the $\mathrm{Na}_{\mathrm{V}}$ isoforms have not been identified in pituitary $\mathrm{GH}_{3}$ cells; however, dorsal root ganglion neurons might express up to five isoforms, which are functionally active in these neurons, e.g., SCN1A-, SCN8A-, SCN9A-, SCN10A-, or SCN11A-encoded current (or $\mathrm{Na}_{V} 1.1, \mathrm{Na}_{V} 1.6, \mathrm{Na}_{V} 1.7, \mathrm{Na}_{V} 1.8$, or $\mathrm{Na}_{V} 1.9$ current) [18,19]. Additional studies 
to delineate the effects of $\mathrm{CBN}$ on $I_{\mathrm{Na}}$ in different cell types that express different isoforms would be warranted.

Earlier and recent studies have demonstrated the ability of CBN to modify the amplitude of voltage-gated $\mathrm{Ca}^{2+}$ currents $[10,16,17]$. However, to some extent distinguishable from those results, the present observations hereby demonstrated that CBN-mediated inhibition of $I_{\mathrm{Na}}$ seen in $\mathrm{GH}_{3}$ cells could be further diminished by SSM, TTX, or Ran but not by Nim. Moreover, as cells were continually exposed to CBN, further addition of Tef, a type-I insecticide known to be an activator of $I_{\mathrm{Na}}$, could effectively reverse CBNmediated reduction in $I_{\mathrm{Na}}$ in response to rapid depolarization. The $\mathrm{IC}_{50}$ values needed for CBN-mediated inhibition of peak and late $I_{\mathrm{Na}}$ observed in this study were estimated to be 14.7 and $2.8 \mu \mathrm{M}$, respectively, the values which were found to be virtually lower than the concentration (i.e., around $100 \mu \mathrm{M}$ ) used either for its block of $\mathrm{Ca}^{2+}$ currents in dorsal root ganglion neurons [10] or for the suppression of prolactin release from $\mathrm{GH}_{3}$ cells [16]. Additionally, according to the binding and unbinding scheme, the $K_{\mathrm{D}}$ value for $\mathrm{CBN}$-mediated perturbation of $I_{\mathrm{Na}}$ inactivation was yielded to be $3.15 \mu \mathrm{M}$. Our study, therefore, reflects that in pituitary or heart cells, the presence of CBN does not appear to interact with plasmalemmal $\mathrm{Ca}^{2+}$ channels exclusively. It is nonetheless possible that aside from the inhibition of $\mathrm{Ca}^{2+}$ currents, $\mathrm{CBN}$ was efficacious at influencing the amplitude and gating kinetics of $I_{\mathrm{Na}}$, which at least a subset of $\mathrm{Na}_{\mathrm{V}}$-channel isoforms constitutes. CBN-mediated perturbation of $\mathrm{Ca}^{2+}$ uptake previously observed in $\mathrm{GH}_{3}$ cells $[16,17]$ could be partly, if not entirely, explained by its inhibitory actions on peak and late components of $I_{\mathrm{Na}}$. Of importance, to what extent CBN-mediated perturbations on the amplitude and gating of $I_{\mathrm{Na}}$ are connected with its alleviation of pain sensation as reported recently $[6,8,10]$, remains to be further resolved.

\section{Materials and Methods}

\subsection{Chemicals and Solutions Used in this Work}

Columbianadin (CBN, zosmin, 2-butenoic acid, 1-(8,9-dihydro-2-oxo-2H-furo(2,3-h)1-benzopyran-8-yl)-1-methylethyl ester, (S-(Z))-, 1-methyl-1-[(8S)-2-oxo-8,9-dihydro-2Hfuro [2,3-h]chromen-8-yl]ethyl (2Z)-2-methylbut-2-enoate, 1-[(8S)-8,9-dihydro-2-oxo-2Hfuro[2,3-h]-1-benzopyran-8-yl]-1-methylethyl-[(2Z)-2-methyl-2-butenoic acid]ester, $\mathrm{C}_{19} \mathrm{H}_{20} \mathrm{O}_{5}$, https:/ / pubchem.ncbi.nlm.nih.gov/compound/Columbianadin) and nimodipine (Nim) were acquired from Cayman Chemical (Asia Bioscience, Taipei, Taiwan), ranolazine (Ran) was obtained from Tocris (Union Biomed, Taipei, Taiwan), dexmedetomidine (DEX) was obtained from Abbott Laboratories (Abbott Park, IL, USA), while ivabradine (IVA), norepinephrine, tefluthrin (Tef), tetraethylammonium chloride (TEA), and tetrodotoxin (TTX) were acquired from Sigma-Aldrich (Merck, Taipei, Taiwan). Sesamin (SSM) was a gift kindly provided by Dr. Ping-Chung Kuo, School of Pharmacy, National Cheng Kung University Medical College, Tainan, Taiwan, whereas chlorotoxin was gifted by Dr. Woei-Jer Chuang, Department of Biochemistry, National Cheng Kung University Medical College. CBN, DEX, IVA, Ran, SSM, or Tef was dissolved in DMSO as $20 \mathrm{mM}$ stock solution, and it was thereafter diluted in extracellular solution to the final concentrations achieved. Stock solution of CBN was wrapped in aluminum foil to avoid photosensitivity [39,40]. Unless stated otherwise, culture media, horse serum, fetal bovine or calf serum, L-glutamine, penicillin-streptomycin, and trypsin/EDTA were acquired from HyClone ${ }^{\mathrm{TM}}$ (Fisher Scientific, Taipei, Taiwan), while all other chemicals, such as aspartic acid, $\mathrm{CsOH}, \mathrm{CsCl}$, EGTA, and HEPES, were of laboratory grade and taken from standard sources.

The HEPES-buffered normal Tyrode's solution used in this work had a composition, which contained (in $\mathrm{mM}$ ): $\mathrm{NaCl} 136.5, \mathrm{KCl} 5.4, \mathrm{CaCl}_{2} 1.8, \mathrm{MgCl}_{2}$ 0.53, glucose 5.5, and HEPES 5.5, and the solution $\mathrm{pH}$ was adjusted to 7.4 with $\mathrm{NaOH}$. For measurements of $I_{\mathrm{Na}}, I_{\mathrm{K}(\mathrm{DR})}$, or $I_{\mathrm{h}}$, we bathed cells in $\mathrm{Ca}^{2+}$-free Tyrode's solution in attempts to remove the contamination of $\mathrm{Ca}^{2+}$-activated $\mathrm{K}^{+}$currents and voltage-gated $\mathrm{Ca}^{2+}$ currents. To record $I_{\mathrm{K}(\mathrm{erg})}$, cells were bathed in high- $\mathrm{K}^{+}, \mathrm{Ca}^{2+}$-free solution, which comprised (in $\mathrm{mM}$ ) $\mathrm{KCl} 130, \mathrm{NaCl} 10, \mathrm{MgCl}_{2}$ 3, and HEPES 5, and the solution $\mathrm{pH}$ was adjusted to 7.4 with 
$\mathrm{KOH}$. For investigations on either $I_{\mathrm{K}(\mathrm{erg})}$ or $I_{\mathrm{h}}$, we filled up the electrode with the internal solution (in mM): K-aspartate 130, $\mathrm{KCl} 20, \mathrm{KH}_{2} \mathrm{PO}_{4} 1, \mathrm{MgCl}_{2}$ 1, EGTA 0.1, $\mathrm{Na}_{2} \mathrm{ATP} 3$, $\mathrm{Na}_{2}$ GTP 0.1, and HEPES 5, adjusted to pH 7.2 with $\mathrm{KOH}$, while for the recordings of $I_{\mathrm{Na}}, \mathrm{K}^{+}$ions in the internal solution were substituted for $\mathrm{Cs}^{+}$ions, and the solution $\mathrm{pH}$ was adjusted to 7.2 with $\mathrm{CsOH}$. All solutions used in this study were prepared using demineralized water from Mill-Q water purification system (Merck, Taipei, Taiwan). On the day of experiments, we commonly filtered the bathing or backfilling solution and culture medium using an Acrodisc $^{\circledR}$ syringe filter with a $0.2-\mu \mathrm{m}$ Supor ${ }^{\circledR}$ nylon membrane (Bio-Check, New Taipei City, Taiwan).

\subsection{Cell Preparations}

$\mathrm{GH}_{3}$, a rat pituitary cell line derived from a pituitary tumor (BCRC-60015), was acquired from the Bioresources Collection and Research Center (Hsinchu, Taiwan) using procedure that we have previously reported [41]. Briefly, $\mathrm{GH}_{3}$ cells were grown as monolayer cultures in Ham's F-12 medium supplemented with 15\% horse serum $(v / v), 2.5 \%$ fetal calf serum $(v / v)$, and $2 \mathrm{mM}$ L-glutamine. The HL-1 atrial cell line was derived from the AT-1 mouse atrial cardiomyocyte tumor lineage, which was originally acquired from Louisiana State University in New Orleans, LA, USA [42]. HL-1 cells were cultured in Claycomb medium (Sigma-Aldrich) supplemented with 10\% fetal bovine serum $(v / v), 100 \mathrm{U} / \mathrm{mL}$ penicillin, $100 \mathrm{mg} / \mathrm{mL}$ streptomycin, $0.1 \mathrm{mM}$ norepinephrine, and $2 \mathrm{mM}$ L-glutamine. $\mathrm{GH}_{3}$ or HL- 1 cells were plated in 100-mm culture dishes $\left(10^{6}\right.$ cells $/$ dish $)$ and maintained at $37{ }^{\circ} \mathrm{C}$ in a humidified environment of $5 \% \mathrm{CO}_{2} / 95 \%$ air. They underwent sub-cultured weekly, and fresh media were replenished every other day to remove nonadhering cells. Subcultures were obtained by trypsinization $\left(0.025 \%\right.$ trypsin solution $\left(\mathrm{HyClone}^{\mathrm{TM}}\right)$ containing $0.01 \%$ sodium n,n-diethyldithiocarbamate and EDTA). Under the experimental conditions studied, cells remained 80-90\% viable for at least 2 weeks. Electrophysiological measurements were performed 5 or 6 days after the cells had been cultured (60-80\% confluence).

\subsection{Electrophysiological Measurements}

On the day of the experiments, $\mathrm{GH}_{3}$ or $\mathrm{HL}-1$ cells were harvested with $1 \%$ trypsin/EDTA solution, and a few drops of cell suspension was rapidly transferred to a home-made recording chamber that was mounted on the XY stage of an inverted DM-IL microscope (Leica; Major Products, New Taipei City, Taiwan). The cells studies were bathed at room temperature $\left(20-25^{\circ} \mathrm{C}\right)$ in HEPES-buffered normal Tyrode's solution, the composition of which is elaborated above. The cells were then allowed to adhere to the bottom of the chamber. To pull the patch electrode from Kimax-51 capillaries (\#34500 (outer diameter: 1.5-1.8 mm); Kimble; Dogger, New Taipei City, Taiwan), we utilized either a P-97 horizontal puller (Sutter; Taiwan Instruments, Tainan, Taiwan) or a PP-83 vertical puller (Narishige; Taiwan Instrument Co., Taipei, Taiwan), and their tips were fire-polished with MF-83 Microforge (Narishige). The electrodes used bore tip resistances between 3 and $5 \mathrm{M} \Omega$ when filled with different internal solutions. An electrode holder which was filled with a silver chloridecoated silver wire connected the patch electrode to the amplifier. During the recordings, the electrode used was maneuvered using an MX-4 manipulator (Narishige) and finely operated by an MHW-3 hydraulic micromanipulator (Narishige). We performed standard patch-clamp recordings under whole-cell configuration by use of either an RK-400 (Biologic, Echirolles, France) or an Axoclamp-2B (Molecular Devices; Advance Biotech, New Taipei City, Taiwan) amplifier [41]. Consistent with previous observations [43], the formation of a bleb of membrane lipids in the electrode tip during microscopic observation of seal formation was also noticed. Giga-seals were generally formed in an all-or-nothing fashion and resulted in a dramatic improvement in signal-to-noise ratio. The junctional potentials, which develop at the electrode tip when the composition of the internal solution differed from that in the bath, were nulled before the start of each giga-seal formation, and such junction potentials corrected whole-cell data. Tested compounds were applied by perfusion (2-3 $\mathrm{mL} / \mathrm{min}$ ) or added to the bath to obtain the final concentration achieved. 


\subsection{Curve-Fitting Procedures and Statistical Analyses}

The pertinent parameters for linear or nonlinear current fitting were appropriately acquired by either nonlinear (e.g., Boltzmann and Hill equation, or single- and twoexponential function) or linear fitting routine, in which the Solver add-in (i.e., the generalized reduced gradient method of iteration) bundled with Excel 2016 (Microsoft, Redmond, WA, USA) or 64-bit OriginPro 2016 (OriginLab; Schmidt Scientific, Kaohsiung, Taiwan) was undertaken [44]. The data acquired in this study are presented as the mean \pm standard error of the mean (SEM), with sample sizes $(n)$ representing the number of cells (e.g., $\mathrm{GH}_{3}$ or HL-1 cells) where the experimental data were taken. Student's $t$-test (paired or unpaired) was initially employed for the statistical analyses; however, as the differences among different groups needed to be further evaluated, we further performed either analysis of variance (ANOVA)-1 or ANOVA-2 with or without repeated measures, which were followed by Duncan's post hoc test. To evaluate the sum of squared residuals (SSR) as a function of the $\mathrm{IC}_{50}$ value for the inhibitory action of $\mathrm{CBN}$ on peak or late $I_{\mathrm{Na}}$, the $95 \%$ confidence interval was estimated using Fisher's $F$ distribution (i.e., FINV function embedded in Microsoft Excel) [44], since the Excel FINV function can calculate the inverse of the right-tailed $F$ probability distribution for a supplied probability. A $p$-value of $<0.05$ was considered to indicate statistical different, unless stated otherwise.

\subsection{Data Recordings}

The signals consisting of voltage and current tracings were monitored and digitally stored at $10 \mathrm{kHz}$ in an Acer SPIN-5 touchscreen laptop computer (SP51-52N-WE; Acer, Taipei, Taiwan), and data acquisition in conjunction with Digidata 1440A (Molecular Devices) was operated by pCLAMP 10.7 software (Molecular Devices). In some of the experiments, wu employed a PowerLab data acquisition via LabChart 7.0 program to digitize signals reliably (AD Instruments; KYS Technology, Tainan, Taiwan). To minimize background noise, the current signals were low-pass filtered at $2 \mathrm{kHz}$ with FL-4 four-pole Bessel filter (Dagan, Minneapolis, MN, USA). Through digital-to-analog conversion, the pCLAMP-generated waveforms (i.e., either rectangular or ramp voltage-clamp command potentials) were specifically designed and applied to the examined cells for the determination of current-voltage $(I-V)$ relationship and study either steady-state activation or inactivation curve of the current specified (e.g., $I_{\mathrm{Na}}$ ). As high-frequency stimuli were needed, we employed an Astro-Med Grass S85X dual output pulse stimulator (Grass, West Warwick, RI, USA).

\subsection{Data Analyses}

To establish percentage inhibition of CBN on the peak and late components of $I_{\mathrm{Na}}$, cells were bathed in $\mathrm{Ca}^{2+}$-free, Tyrode's solution, the examined cell was voltage-clamped at $-80 \mathrm{mV}$, and the $40-\mathrm{ms}$ depolarizing pulse from -80 to $-10 \mathrm{mV}$ was thereafter delivered to evoke $I_{\mathrm{Na}}$. Current amplitudes during the application of varying CBN concentrations were compared with those measured after subsequent addition of TTX $(1 \mu \mathrm{M})$. The concentrationdependent relation of CBN on the inhibition of $I_{\mathrm{Na}}$ measured at the start or end of the 40-ms depolarizing pulse from -80 to $-10 \mathrm{mV}$ was appropriately fitted to the Hill equation (i.e., the multiparameter logistic equation). That is,

$$
\text { Percentage inhibition }=\frac{[\mathrm{CBN}]^{n_{\mathrm{H}}} \times \mathrm{E}_{\max }}{[\mathrm{CBN}]^{n_{\mathrm{H}}}+\mathrm{IC}_{50}^{n_{\mathrm{H}}}},
$$

where $[\mathrm{CBN}]$ is the $\mathrm{CBN}$ concentration; $\mathrm{IC}_{50}$ or $\mathrm{n}_{\mathrm{H}}$ is the $\mathrm{CBN}$ concentration for $50 \% I_{\mathrm{Na}}$ inhibition or the Hill coefficient, respectively; and $\mathrm{E}_{\max }$ is the $\mathrm{CBN}$-induced maximal inhibition of peak or late $I_{\mathrm{Na}}$ (i.e., TTX-sensitive current). 
The inhibitory effect of $\mathrm{CBN}$ on $I_{\mathrm{Na}}$ is thought to ascribe from a state-dependent blocker that binds predominantly to the open state of the Na channel [22]. Based on this simplifying assumption, a minimal kinetic scheme was thereafter given as follows:

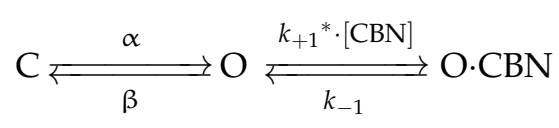

or,

$$
\begin{gathered}
\frac{d C}{d t}=O \times \beta-C \times \alpha \\
\frac{d O}{d t}=C \times \alpha+O \cdot C B N \times k_{-1}-O \times \beta-O \times k_{+1}^{*} \cdot[\mathrm{CBN}] \\
\frac{d(O \cdot C B N)}{d t}=O \times k_{+1}^{*} \cdot[C B N]-O \cdot C B N \times k_{-1},
\end{gathered}
$$

where $[\mathrm{CBN}]$ is the $\mathrm{CBN}$ concentration applied and $\alpha$ or $\beta$ is the voltage-gated rate constant for the opening or closing of the $\mathrm{Na}_{\mathrm{V}}$ channel elicited by rapid step depolarization, respectively. $k_{+1}{ }^{*}$ or $k_{-1}$ indicates the forward (i.e., on or blocking) or backward (i.e., off or unblocking) rate constant of $\mathrm{CBN}$, respectively, whereas $\mathrm{C}, \mathrm{O}$, or O.CBN in each term represents the closed (resting), open, or open-blocked state, respectively.

The value of $k_{+1}{ }^{*}$ or $k_{-1}$ was calculated on the basis of the time constant of the slow component in $I_{\mathrm{Na}}$ inactivation $\left(\tau_{\text {inact(S) }}\right)$ in response to 40 -ms depolarizing pulse achieved during the exposure to varying CBN concentrations. By virtue of the abovedescribed binding scheme, these rate constants could be allowed to be optimized using the following equation:

$$
\frac{1}{\tau_{\text {inact }(S)}}=[C B N] \times k_{+1}^{*}+k_{-1}
$$

where $k_{+1}{ }^{*}$ or $k_{-1}$ can be derived from the slope or from the $y$-axis intercept at [CBN] $=0$ of the linear regression, which interpolates the reciprocal time constants (i.e., $1 / \tau_{\text {inact(S) }}$ ) versus the $\mathrm{CBN}$ concentration used, and $[\mathrm{CBN}]$ is the $\mathrm{CBN}$ concentration. A measure of the dissociation constant $\left(K_{\mathrm{D}}\right)$ equal to the $k_{-1}$ value divided by the value of [CBN] $k_{+1}{ }^{*}$ can thereafter reliably be yielded.

The steady-state activation or inactivation curve of peak $I_{\mathrm{Na}}$ with or without the CBN addition was established and plotted against either membrane or conditioning potential, respectively, and the sigmoidal curve of the current was least-squares fitted by the Boltzmann equation (or the Fermi-Dirac distribution) [33]:

$$
I\left(\text { or } G_{N a}\right)=\frac{I_{\max }\left(\operatorname{or} G_{N a(\max )}\right)}{1+e^{\frac{ \pm\left(V-V_{1 / 2) \times q \times F}\right.}{R T}}},
$$

where $I_{\max }$ or $G_{\mathrm{Na}(\max )}$, respectively, indicates the maximal amplitude or conductance of $I_{\mathrm{Na}}$ in the absence and presence of $\mathrm{CBN}(10 \mu \mathrm{M}) ; V$ is the membrane or conditioning potential in $\mathrm{mV} ; \mathrm{V}_{1 / 2}$ is the membrane potential at which half-maximal activation or inactivation of $I_{\mathrm{Na}}$ is achieved; $q$ is the apparent activation or inactivation gating charge; $F$ is Faraday's constant; $R$ is the universal gas constant; and $T$ is the absolute temperature.

Author Contributions: Conceptualization, W.-T.C. and S.-N.W.; methodology, S.-N.W.; software, S.-N.W.; validation, W.-T.C. and S.-N.W.; formal analysis, S.-N.W.; investigation, W.-T.C. and S.-N.W.; resources, S.-N.W.; data curation, S.-N.W.; writing-original draft preparation, S.-N.W.; writingreview and editing, W.-T.C. and S.-N.W.; visualization, W.-T.C. and S.-N.W.; supervision, S.-N.W.; project administration, S.-N.W.; funding acquisition, S.-N.W. All authors have read and agreed to the published version of the manuscript.

Funding: This work was partly aided by a grant from the Ministry of Science and Technology (MOST-108-2314-B-006-094; 109-2326-B-384 -001 -MY3), Taiwan.

Institutional Review Board Statement: Not applicable. 
Informed Consent Statement: Not applicable.

Data Availability Statement: The original data is available upon reasonable request to the corresponding author.

Acknowledgments: The authors are grateful to K.Z.-H. and L.S.-W. for their technical assistances.

Conflicts of Interest: The authors declare that they have no conflicts of interest, financial or otherwise. The authors are responsible for the content of writing of the paper.

\section{Abbreviations}

$\begin{array}{ll}\text { ANOVA } & \text { analysis of variance } \\ \text { CBN } & \text { columbianadin } \\ \text { DEX } & \text { dexmedetomidine } \\ G_{\mathrm{Na}} & \mathrm{Na}^{+} \text {-current conductance } \\ \mathrm{I}-\mathrm{V} & \text { current versus voltage } \\ \mathrm{IC}_{50} & \text { half-maximal inhibitory concentration } \\ I_{\mathrm{h}} & \text { hyperpolarization-activated cation current } \\ I_{\mathrm{K}(\mathrm{erg})} & \text { erg-mediated } \mathrm{K}^{+} \text {current } \\ I_{\mathrm{Na}} & \text { voltage-gated } \mathrm{Na}^{+} \text {current } \\ \mathrm{IVA} & \text { ivabradine } \\ K_{\mathrm{D}} & \text { dissociation constant } \\ \mathrm{Na} & \text { voltage-gated } \mathrm{Na}^{+} \text {channel } \\ \mathrm{Nim} & \text { nimodipine } \\ \mathrm{Ran} & \text { ranolazine } \\ \text { SEM } & \text { standard error of mean } \\ \text { SSM } & \text { sesamin } \\ \text { SSR } & \text { sum of the squared residuals } \\ \tau_{\text {inact(S) }} & \text { time constant for the slow component of } I_{\mathrm{Na}} \text { inactivation } \\ \text { Tef } & \text { tefluthrin } \\ \text { TEA } & \text { tetraethylammonium chloride } \\ \text { TTX } & \text { tetrodotoxin }\end{array}$

\section{References}

1. Chen, Y.F.; Tsai, H.Y.; Wu, T.S. Anti-inflammatory and analgesic activities from roots of Angelica pubescens. Planta Med. 1995, 61, 2-8. [CrossRef] [PubMed]

2. Zhang, C.; Hsu, A.C.; Pan, H.; Gu, Y.; Zuo, X.; Dong, B.; Wang, Z.; Zheng, J.; Lu, J.; Zheng, R.; et al. Columbianadin Suppresses Lipopolysaccharide (LPS)-Induced Inflammation and Apoptosis through the NOD1 Pathway. Molecules 2019, 24, 549. [CrossRef] [PubMed]

3. Zhang, Y.B.; Li, W.; Yang, X.W. Biotransformation of columbianadin by rat hepatic microsomes and inhibition of biotransformation products on NO production in RAW 264.7 cells in vitro. Phytochemistry 2012, 81, 109-116. [CrossRef] [PubMed]

4. Lim, H.J.; Lee, J.H.; Choi, J.S.; Lee, S.K.; Kim, Y.S.; Kim, H.P. Inhibition of airway inflammation by the roots of Angelica decursiva and its constituent, columbianadin. J. Ethnopharmacol. 2014, 155, 1353-1361. [CrossRef] [PubMed]

5. Hou, S.M.; Hsia, C.W.; Tsai, C.L.; Hsia, C.H.; Jayakumar, T.; Velusamy, M.; Sheu, J.R. Modulation of human platelet activation and in vivo vascular thrombosis by columbianadin: Regulation by integrin alphallbbeta3 inside-out but not outside-in signals. J. Biomed. Sci. 2020, 27, 60. [CrossRef] [PubMed]

6. Ma, J.; Huang, J.; Hua, S.; Zhang, Y.; Zhang, Y.; Li, T.; Dong, L.; Gao, Q.; Fu, X. The ethnopharmacology, phytochemistry and pharmacology of Angelica biserrata-A review. J. Ethnopharmacol. 2019, 231, 152-169. [CrossRef] [PubMed]

7. Yang, Y.; Zhu, R.; Li, J.; Yang, X.; He, J.; Wang, H.; Chang, Y. Separation and Enrichment of Three Coumarins from Angelicae Pubescentis Radix by Macroporous Resin with Preparative HPLC and Evaluation of Their Anti-Inflammatory Activity. Molecules 2019, 24, 2664. [CrossRef]

8. Lu, T.L.; Lu, T.J.; Wu, S.N. Effectiveness in Block by Dexmedetomidine of Hyperpolarization-Activated Cation Current, Independent of Its Agonistic Effect on alpha2-Adrenergic Receptors. Int. J. Mol. Sci. 2020, 21, 9110. [CrossRef] [PubMed]

9. Li, R.; Zhao, C.; Yao, M.; Song, Y.; Wu, Y.; Wen, A. Analgesic effect of coumarins from Radix angelicae pubescentis is mediated by inflammatory factors and TRPV1 in a spared nerve injury model of neuropathic pain. J. Ethnopharmacol. 2017, 195, 81-88. [CrossRef]

10. Su, X.; Wu, B.; Zhang, W.; Ji, Y.H.; Wang, Q.; Tan, Z.Y. Inhibitory Effects of Columbianadin on Nociceptive Behaviors in a Neuropathic Pain Model, and on Voltage-Gated Calcium Currents in Dorsal Root Ganglion Neurons in Mice. Front. Pharmacol. 2019, 10, 1522. [CrossRef] 
11. Wan, M.Q.; Liu, X.Y.; Gao, H.; Wang, T.X.; Yang, Y.F.; Jia, L.Y.; Yang, X.W.; Zhang, Y.B. Systematic analysis of the metabolites of Angelicae Pubescentis Radix by UPLC-Q-TOF-MS combined with metabonomics approaches after oral administration to rats. J. Pharm. Biomed. Anal. 2020, 188, 113445. [CrossRef] [PubMed]

12. Yu, J.; Zhong, B.; Xiao, Q.; Du, L.; Hou, Y.; Sun, H.S.; Lu, J.J.; Chen, X. Induction of programmed necrosis: A novel anti-cancer strategy for natural compounds. Pharmacol. Ther. 2020, 214, 107593. [CrossRef] [PubMed]

13. Yerer, M.B.; Dayan, S.; Han, M.I.; Sharma, A.; Tuli, H.S.; Sak, K. Nanoformulations of Coumarins and the Hybrid Molecules of Coumarins with Potential Anticancer Effects. Anticancer Agents Med. Chem. 2020, 20, 1797-1816. [CrossRef]

14. Kang, J.I.; Hong, J.Y.; Choi, J.S.; Lee, S.K. Columbianadin Inhibits Cell Proliferation by Inducing Apoptosis and Necroptosis in HCT116 Colon Cancer Cells. Biomol. Ther. 2016, 24, 320-327. [CrossRef]

15. Lu, Y.; Wu, H.; Yu, X.; Zhang, X.; Luo, H.; Tang, L.; Wang, Z. Traditional Chinese Medicine of Angelicae Pubescentis Radix: A Review of Phytochemistry, Pharmacology and Pharmacokinetics. Front. Pharmacol. 2020, 11, 335. [CrossRef]

16. Vuorela, H.; Vuorela, P.; Tornquist, K.; Alaranta, S. Calcium channel blocking activity: Screening methods for plant derived compounds. Phytomedicine 1997, 4, 167-180. [CrossRef]

17. Tornquist, K.; Vuorela, H. The furanocoumarin columbianadin inhibits depolarization induced Ca2+ uptake in rat pituitary GH3 cells. Planta Med. 1990, 56, 127-129. [CrossRef] [PubMed]

18. Yu, F.H.; Catterall, W.A. Overview of the voltage-gated sodium channel family. Genome Biol. 2003, 4, 207. [CrossRef] [PubMed]

19. Catterall, W.A.; Goldin, A.L.; Waxman, S.G. International Union of Pharmacology. XLVII. Nomenclature and structure-function relationships of voltage-gated sodium channels. Pharmacol. Rev. 2005, 57, 397-409. [CrossRef]

20. Stojilkovic, S.S.; Tabak, J.; Bertram, R. Ion channels and signaling in the pituitary gland. Endocr. Rev. 2010, 31, 845-915. [CrossRef]

21. Chen, B.S.; Lo, Y.C.; Peng, H.; Hsu, T.I.; Wu, S.N. Effects of ranolazine, a novel anti-anginal drug, on ion currents and membrane potential in pituitary tumor GH(3) cells and NG108-15 neuronal cells. J. Pharmacol. Sci. 2009, 110, 295-305. [CrossRef] [PubMed]

22. Lo, Y.C.; Tseng, Y.T.; Liu, C.M.; Wu, B.N.; Wu, S.N. Actions of KMUP-1, a xanthine and piperazine derivative, on voltage-gated $\mathrm{Na}(+)$ and $\mathrm{Ca}(2+)$-activated $\mathrm{K}(+)$ currents in GH3 pituitary tumour cells. Br. J. Pharmacol. 2015, 172, 5110-5122. [CrossRef]

23. Simasko, S.M. A background sodium conductance is necessary for spontaneous depolarizations in rat pituitary cell line GH3. Am. J. Physiol. 1994, 266, C709-C719. [CrossRef] [PubMed]

24. Rosen, A.D. Nonlinear temperature modulation of sodium channel kinetics in GH(3) cells. Biochim. Biophys. Acta 2001, 1511,391-396. [CrossRef]

25. Kuo, P.C.; Kao, Z.H.; Lee, S.W.; Wu, S.N. Effects of Sesamin, the Major Furofuran Lignan of Sesame Oil, on the Amplitude and Gating of Voltage-Gated $\mathrm{Na}(+)$ and $\mathrm{K}(+)$ Currents. Molecules 2020, 25, 62. [CrossRef] [PubMed]

26. Wu, S.N.; Lo, Y.K.; Li, H.F.; Shen, A.Y. Functional coupling of voltage-dependent L-type Ca2+ current to Ca2+-activated K+ current in pituitary GH3 cells. Chin. J. Physiol. 2001, 44, 161-167. [PubMed]

27. Wu, S.N.; Wu, Y.H.; Chen, B.S.; Lo, Y.C.; Liu, Y.C. Underlying mechanism of actions of tefluthrin, a pyrethroid insecticide, on voltage-gated ion currents and on action currents in pituitary tumor (GH3) cells and GnRH-secreting (GT1-7) neurons. Toxicology 2009, 258, 70-77. [CrossRef]

28. So, E.C.; Wu, S.N.; Lo, Y.C.; Su, K. Differential regulation of tefluthrin and telmisartan on the gating charges of INa activation and inactivation as well as on resurgent and persistent INa in a pituitary cell line (GH3). Toxicol. Lett. 2018, 285, 104-112. [CrossRef]

29. Simasko, S.M.; Sankaranarayanan, S. Characterization of a hyperpolarization-activated cation current in rat pituitary cells. Am. J. Physiol. 1997, 272, E405-E414. [CrossRef]

30. Wei, F.; Wang, Q.; Han, J.; Goswamee, P.; Gupta, A.; McQuiston, A.R.; Liu, Q.; Zhou, L. Photodynamic Modification of Native HCN Channels Expressed in Thalamocortical Neurons. ACS Chem. Neurosci. 2020, 11, 851-863. [CrossRef]

31. Hsiao, H.T.; Liu, Y.C.; Liu, P.Y.; Wu, S.N. Concerted suppression of Ih and activation of IK(M) by ivabradine, an HCN-channel inhibitor, in pituitary cells and hippocampal neurons. Brain Res. Bull. 2019, 149, 11-20. [CrossRef] [PubMed]

32. Armstrong, C.M.; Bezanilla, F. Currents related to movement of the gating particles of the sodium channels. Nature 1973, 242, 459-461. [CrossRef] [PubMed]

33. Villalba-Galea, C.A. Hysteresis in voltage-gated channels. Channels 2017, 11, 140-155. [CrossRef] [PubMed]

34. Yang, X.W.; Guo, Q.M.; Wang, Y. [Absorption and transport of 6 coumarins isolated from the roots of Angelica pubescens $\mathrm{f}$. biserrata in human Caco-2 cell monolayer model]. Zhong Xi Yi Jie He Xue Bao 2008, 6, 392-398. [CrossRef]

35. Zhang, Y.B.; Yang, X.W. Tissue distribution study of columbianadin and its active metabolite columbianetin in rats. Biomed. Chromatogr. 2016, 30, 256-262. [CrossRef]

36. Ge, Y.; Chen, S.; Luo, Q.; Wang, C.P.; Hao, J.; He, J.; Chen, X.; Yang, X.; Li, J.; Chang, Y.X. The Tissue Distribution of Four Major Coumarins after Oral Administration of Angelicae Pubescentis Radix Extract to Rats Using Ultra-High-Performance Liquid Chromatography. Evid. Based Complement. Altern. Med. 2019, 2019, 2365697. [CrossRef]

37. Li, J.; Li, Z.; Luo, Q.; Wang, C.P.; He, J.; Pang, X.; Teye Azietaku, J.; Chang, Y.X. Simultaneous Determination of Columbianadin and Its Metabolite Columbianetin in Rat Plasma by LC-MS/MS: Application to Pharmacokinetics of Columbianadin after Oral Administration. Evid. Based Complement. Altern. Med. 2018, 2018, 8568303. [CrossRef]

38. Chang, Y.X.; Wang, C.P.; Li, J.; Bai, Y.; Luo, Q.; He, J.; Lu, B.; Wang, T.; Zhang, B.L.; Gao, X.M. LC-MS/MS determination and pharmacokinetic study of columbianadin in rat plasma after intravenous administration of pure columbianadin. Chem. Cent. $J$. 2014, 8, 64. [CrossRef] 
39. Damour, O.; Augustin, C.; Black, A.F. Applications of reconstructed skin models in pharmaco-toxicological trials. Med. Biol. Eng. Comput. 1998, 36, 825-832. [CrossRef]

40. Abraham, J.P.; Joe, I.H.; George, V.; Nielsen, O.F.; Jayakumar, V.S. Vibrational spectroscopic studies on the natural product, columbianadin. Spectrochim. Acta A Mol. Biomol. Spectrosc. 2003, 59, 193-199. [CrossRef]

41. Wu, S.N.; Chern, J.H.; Shen, S.; Chen, H.H.; Hsu, Y.T.; Lee, C.C.; Chan, M.H.; Lai, M.C.; Shie, F.S. Stimulatory actions of a novel thiourea derivative on large-conductance, calcium-activated potassium channels. J. Cell Physiol. 2017, 232, 3409-3421. [CrossRef] [PubMed]

42. Claycomb, W.C.; Lanson, N.A., Jr.; Stallworth, B.S.; Egeland, D.B.; Delcarpio, J.B.; Bahinski, A.; Izzo, N.J., Jr. HL-1 cells: A cardiac muscle cell line that contracts and retains phenotypic characteristics of the adult cardiomyocyte. Proc. Natl. Acad. Sci. USA 1998, 95, 2979-2984. [CrossRef] [PubMed]

43. Milton, R.L.; Caldwell, J.H. How do patch clamp seals form? A lipid bleb model. Pflügers Archiv 1990, 416, 758-762. [CrossRef] [PubMed]

44. Kemmer, G.; Keller, S. Nonlinear least-squares data fitting in Excel spreadsheets. Nat. Protoc. 2010, 5, 267-281. [CrossRef] [PubMed] 